\title{
Hotspots of gross emissions from the land use sector: patterns, uncertainties, and leading emission sources for the period 2000-2005 in the tropics
}

\author{
Rosa Maria Roman-Cuesta ${ }^{1,2}$, Mariana C. Rufino ${ }^{1}$, Martin Herold ${ }^{2}$, Klaus Butterbach-Bahl ${ }^{3,4}$, Todd S. Rosenstock ${ }^{5}$, \\ Mario Herrero $^{6}$, Stephen Ogle ${ }^{7}$, Changsheng Li $^{8, \dagger}$, Benjamin Poulter ${ }^{9}$, Louis Verchot ${ }^{1,10}$, Christopher Martius ${ }^{1}$, \\ John Stuiver ${ }^{2}$, and Sytze de Bruin ${ }^{2}$ \\ ${ }^{1}$ Center for International Forestry Research (CIFOR), P.O. Box 0113 BOCBD, Bogor 16000, Indonesia \\ ${ }^{2}$ Laboratory of Geo-Information Science and Remote Sensing, Wageningen University, Droevendaalsesteeg 3 , \\ 6708 PB Wageningen, the Netherlands \\ ${ }^{3}$ International Livestock Research Institute (ILRI), P.O. Box 30709, Nairobi 00100, Kenya \\ ${ }^{4}$ Karlsruhe Institute of Technology, Institute of Meteorology and Climate Research (IMK-IFU), \\ Garmisch-Partenkirchen, Germany \\ ${ }^{5}$ World Agroforestry Centre (ICRAF), PO Box 30677-00100, Nairobi, Kenya \\ ${ }^{6}$ Commonwealth Scientific and Industrial Research Organisation, Agriculture Flagship, 306 Carmody Road, \\ St Lucia, QLD 4067, Australia \\ ${ }^{7}$ Natural Resource Ecology Laboratory, Campus Delivery 1499, Colorado State University, Fort Collins, \\ Colorado 80523-1499, USA \\ ${ }^{8}$ Institute for the Study of Earth, Oceans, and Space, University of New Hampshire, Durham, NH 03824, USA \\ ${ }^{9}$ Ecosystem Dynamics Laboratory, Montana State University, P.O. Box 172000, Bozeman, MT 59717-2000, USA \\ ${ }^{10}$ Earth Institute Center for Environmental Sustainability, Columbia University, New York, USA \\ †deceased \\ Correspondence to: Rosa Maria Roman-Cuesta (rosa.roman@wur.nl)
}

Received: 16 March 2016 - Published in Biogeosciences Discuss.: 22 March 2016

Revised: 28 June 2016 - Accepted: 6 July 2016 - Published: 29 July 2016

\begin{abstract}
According to the latest report of the Intergovernmental Panel on Climate Change (IPCC), emissions must be cut by $41-72 \%$ below 2010 levels by 2050 for a likely chance of containing the global mean temperature increase to $2{ }^{\circ} \mathrm{C}$. The AFOLU sector (Agriculture, Forestry and Other Land Use) contributes roughly a quarter $\left(\sim 10-12 \mathrm{PgCO}_{2} \mathrm{e} \mathrm{yr}^{-1}\right)$ of the net anthropogenic GHG emissions mainly from deforestation, fire, wood harvesting, and agricultural emissions including croplands, paddy rice, and livestock. In spite of the importance of this sector, it is unclear where the regions with hotspots of AFOLU emissions are and how uncertain these emissions are. Here we present a novel, spatially comparable dataset containing annual mean estimates of gross AFOLU emissions $\left(\mathrm{CO}_{2}, \mathrm{CH}_{4}, \mathrm{~N}_{2} \mathrm{O}\right)$, associated uncertainties, and leading emission sources, in a spatially disaggre-
\end{abstract}

gated manner $\left(0.5^{\circ}\right)$ for the tropics for the period 2000-2005. Our data highlight the following: (i) the existence of AFOLU emissions hotspots on all continents, with particular importance of evergreen rainforest deforestation in Central and South America, fire in dry forests in Africa, and both peatland emissions and agriculture in Asia; (ii) a predominant contribution of forests and $\mathrm{CO}_{2}$ to the total AFOLU emissions $(69 \%)$ and to their uncertainties (98\%); (iii) higher gross fluxes from forests, which coincide with higher uncertainties, making agricultural hotspots appealing for effective mitigation action; and (iv) a lower contribution of non- $\mathrm{CO}_{2}$ agricultural emissions to the total gross emissions (ca. $25 \%$ ), with livestock $(15.5 \%)$ and rice $(7 \%)$ leading the emissions. Gross AFOLU tropical emissions of 8.0 (5.5-12.2) were in the range of other databases $\left(8.4\right.$ and $8.0 \mathrm{PgCO}_{2} \mathrm{e} \mathrm{yr}^{-1}$ in 
FAOSTAT and the Emissions Database for Global Atmospheric Research (EDGAR) respectively), but we offer a spatially detailed benchmark for monitoring progress in reducing emissions from the land sector in the tropics. The location of the AFOLU hotspots of emissions and data on their associated uncertainties will assist national policy makers, investors, and other decision-makers who seek to understand the mitigation potential of the AFOLU sector.

\section{Introduction}

Currently, unabated $\mathrm{CO}_{2} \mathrm{e}$ emissions need effective mitigation action (UNEP, 2015). Emissions modelling suggests that to keep the global mean temperature increase on track to reach the $2{ }^{\circ} \mathrm{C}$ target and to remain close to the target of $450 \mathrm{ppm}$ of $\mathrm{CO}_{2} \mathrm{e}$ by 2100 , global greenhouse gas (GHG) emissions must be cut to $41-72 \%$ below the 2010 levels by 2050, and global emissions levels must be reduced to 0 (a balance between sources and sinks) by 2070 and below 0 through removal processes after that (IPCC, 2014; Anderson, 2015; UNEP, 2015). To reach these ambitious goals, it is imperative to identify regions where the mitigation of key emission sectors may be most promising in terms of reducing fluxes, reducing emission trends, and/or maximizing returns on mitigation investments. Of all the sectors contributing to the total anthropogenic GHG emissions, the Agriculture, Forestry and Other Land Use (AFOLU) sector participates with roughly one quarter $\left(10-12 \mathrm{Pg} \mathrm{CO}_{2} \mathrm{e} \mathrm{yr}^{-1}\right)$ of the total emissions (49 $\mathrm{Pg} \mathrm{CO}_{2} \mathrm{e} \mathrm{yr}^{-1}$; IPCC, 2014). Optimistic estimates suggest that the AFOLU sector - here used as synonym of land use sector - could contribute 20 to $60 \%$ of the total cumulative abatement to 2030 through land-related mitigation including bioenergy (Smith et al., 2014). However, it is unclear where the regions with the largest AFOLU emissions (hotspots of emissions) are and how large their associated uncertainties are.

Modelling efforts by the carbon community have long offered useful data, but their focus is rather global and $\mathrm{CO}_{2}$ oriented, which omits other land use gases such as $\mathrm{CH}_{4}$ and $\mathrm{N}_{2} \mathrm{O}$ (Schulze et al., 2009; Houghton et al., 2012; Le Quéré et al., 2014; Canadell and Schulze, 2014; Tian et al., 2016). Currently, the most used AFOLU data are found in to two global multi-gas $\left(\mathrm{CO}_{2}, \mathrm{CH}_{4}, \mathrm{~N}_{2} \mathrm{O}\right) \mathrm{CO}_{2}$ e databases: FAOSTAT and the Emissions Database for Global Atmospheric Research (EDGAR); Smith et al., 2014; Tubiello et al., 2015). While they offer very valuable data, they suffer from several shortcomings: they do not provide uncertainties or uncertainties are not provided on the spatial scale on which emissions are offered; they suffer from untransparent documentation (e.g. EDGAR) or data are offered on inappropriate spatial scales to effectively navigate mitigation implementation (e.g. country level in FAOSTAT). Thus, unlike aggregated estimates, spatially explicit data favour tar- geted mitigation action and implementation by identifying where the areas within a country that hold the largest emissions are and what the key emission sources to address in these areas are (e.g. deforestation, degradation, livestock, cropland soils, paddy rice). Spatially explicit assessments of AFOLU emissions and their associated uncertainties would assist national policy makers, investors, and other decisionmakers who seek to understand the mitigation potential of the AFOLU sector, and would indicate which areas to prioritize This potential is here defined as the maximum mitigation reduction that could be achieved without technical or economic considerations. Better understanding of the AFOLU mitigation potentials will also be important under the Paris Agreement (PA) since the fulfilment of the $2{ }^{\circ} \mathrm{C}$ target is dependent on the mitigation ambition presented by countries in their Nationally Determined Contributions (NDCs). To safeguard this ambition a stock-take process has been defined, by which countries are required to update their NDCs every 5 years, starting from 2020, and to enhance their mitigation commitments from previous submissions (Bodle et al., 2016). It is therefore imperative to improve our understanding of where and how much countries could enhance their AFOLU ambition based on what they have currently reported.

Mitigation action can be directed to reducing emissions by the sources or to increasing the absorptions by the sinks or to both. While gross and net emissions are equally important, they offer different information (Richter and Houghton, 2011; Houghton et al., 2012). Net land use emissions represent the sum of emissions by sources and removals by sinks. Land use sinks refer to any process that stores GHGs (e.g. forest growth, forest regrowth after disturbances, organic matter stored in soils; see Richter and Houghton, 2011, for further details). Countries report their emissions and their reduction targets based on net AFOLU balances (IPCC, 2006; Iversen et al., 2014; Smith et al., 2014). Assessments of gross emissions offer separate data on emissions by sources (gross emissions) and removals by sinks (gross removals) and are useful for designing mitigation implementation because they offer direct information on the sources and sinks that may be acted upon through policies and measures to enhance and promote mitigation. However, lack of ground data makes the assessment of gross sinks much more difficult than the assessment of gross sources (Lewis et al., 2009; Houghton et al., 2012; Grace et al., 2014; Brienen et al., 2015), with a particular gap regarding disturbed standing forests (Poorter et al., 2016).

For these reasons, we present here an assessment of AFOLU gross emissions only for the tropics and subtropics. We exclude sinks (e.g. regrowth of cleared forests or burned areas and soil carbon storage). We offer spatially explicit $\left(0.5^{\circ}\right)$ multi-gas $\left(\mathrm{CO}_{2}, \mathrm{CH}_{4}, \mathrm{~N}_{2} \mathrm{O}\right) \mathrm{CO}_{2} \mathrm{e}$ gross emission data that help identify the hotspots of land use emissions in the tropics and subtropics and associated uncertainties for 20002005. Our method uses a consistent approach to overcome problems of different definitions, methods, and input data 
present in other approaches (e.g. nationally reported data), allowing data comparability. It is a top-down approach based on published, spatially explicit GHG datasets for the key sources of emissions in the AFOLU sector as identified in the Fifth Assessment Report of the IPCC (AR5; Smith et al., 2014): deforestation, fire, wood harvesting, crop soil emissions, paddy rice emission, enteric fermentation, and manure management. We address three questions on landscape, tropical, and continental scales:

1. Where are the hotspots of tropical AFOLU emissions and how uncertain are they?

2. What are the main GHGs emissions behind these hotspots?

3. What are the emission sources behind these hotspots?

4. How do our gross AFOLU emissions relate to other AFOLU datasets such as FAOSTAT or EDGAR?

\section{Material and methods}

Our study area covers the tropics and the subtropics, including the more temperate regions of South America $\left(33^{\circ} \mathrm{N}\right.$ to $54^{\circ} \mathrm{S}, 161^{\circ} \mathrm{E}$ to $117^{\circ} \mathrm{W}$ ). It extends over a diversity of ecosystems that range from dry woodlands and dry forests such as the African miombo and South American Chaco, to rainforests and moist forests such as evergreen broadleaved rainforests or montane cloud forests. The years considered by our datasets varied, but we selected the period 2000-2005 as the common temporal range for all the datasets. The exception was the rice emissions dataset, which took 2010 as its baseline (See Table S2 in the Supplement). This time period represents a useful historical baseline against which countries can contrast the evolution of their AFOLU gross emission performances. We consider the pixel size $\left(0.5^{\circ}\right)$ appropriate for landscape research and useful to visualize emissions hotspots. More detailed information about each data source and a descriptive summary is available in the Supplement (Table S2).

\subsection{Datasets}

\subsubsection{Harris et al. (2012)}

Deforestation refers to gross emissions, associated with the area of forest cover loss (above-ground and below-ground biomass) due to human or natural disturbances at a spatial resolution of $18.5 \mathrm{~km}$ and aggregated in a 5 -year period (2000-2005). Deforestation areas are based on MODIS data at $18.5 \mathrm{~km}$ resolution, while carbon loss derives from the Saatchi et al. (2011) carbon map at $1 \mathrm{~km}$ resolution. The disparate spatial resolution of these two maps is solved by a randomization procedure (Harris et al., 2012). Information of uncertainties is expressed as 5th and 95th percentiles, estimated through Monte Carlo simulations, and showed nonGaussian distributions. The data of Harris et al. (2012) define the spatial and temporal extent of our tropical AFOLU analysis.

\subsubsection{Fire (Van der Werf et al., 2010)}

Fire emissions $\left(\mathrm{CO}_{2}, \mathrm{CH}_{4}, \mathrm{~N}_{2} \mathrm{O}\right)$ were obtained from the Global Fire Emission Database (GFED) at $0.5^{\circ}$ resolution, based on the Carnegie-Ames-Stanford Approach (CASA) model, which includes four carbon pools (above- and belowground biomass, litter, and coarse woody debris). Only carbon from organic soils was included. Original data had global coverage for the period 1997-2013. We extracted a subset for the tropics and 2000-2005. Annual uncertainties for different regions are expressed in Van der Werf et al. (2010) as the 5th, 25th, 50th, 75th, and 95th percentiles of 2000 Monte Carlo runs. Uncertainties of $1 \sigma$ (expressed as percentage of the 50th percentile) were also given and considered to be Gaussian distributions. To move to pixel $\left(0.5^{\circ}\right)$ uncertainties, we assigned the regional $1 \sigma$ to all the pixels within each region for each gas. Total fire emissions $\left(\mathrm{CO}_{2} \mathrm{e}\right)$ per pixel were the sum of the annual means. The uncertainties of the different gases $\left(\mathrm{CH}_{4}, \mathrm{~N}_{2} \mathrm{O}\right.$, and $\left.\mathrm{CO}_{2}\right)$ were assumed independent and estimated by square rooting the sum of their variances. Fire emissions are partitioned into six classes (savannah, agriculture, woodlands, forests, peatlands, and deforestation), which helped us remove $\mathrm{CO}_{2}$ emissions from savannahs and agriculture since the burning of these non-woody land uses is assumed to be carbon neutral (e.g. biomass burned land is recovered by biomass growth in the next growing season; IPCC, 2006). $\mathrm{CH}_{4}$ and $\mathrm{N}_{2} \mathrm{O}$ emissions were, however, retained. We also removed deforestation fires, to avoid double counting with deforestation emissions from Harris et al. (2012). Some overlapping of deforestation and soil peat burning may, however, occur where peat fires and deforestation fires show similar fire recurrences and may be wrongly labelled (Van der Werf et al., 2010). Some peat fires may, therefore, respond to deforestation fires and cause some double counting with Harris deforestation emissions. This would only affect Indonesia since it is the only country that counts on spatially explicit peatland maps (Van der Werf et al., 2010) and would therefore represent a small bias.

\subsubsection{Wood harvesting (Poulter et al., 2015)}

Wood harvesting is a $1^{\circ}$ global gridded data set, generated in the frame of the GEOCARBON project. It uses National Forest Inventory data and the FAO Forest Resources Assessment (FRA). Above-ground biomass data were downscaled using a forest mask from the Global Land Cover (GLC) 2000 and assuming that wood harvest was distributed evenly. The original data were produced at the resolution of the GLC2000 (approx. $1 \times 1 \mathrm{~km}$ ) and finally aggregated to the $1^{\circ}$ scale. 
Table 1. Data conversions to $\mathrm{CO}_{2}$ e for different chemical elements $(\mathrm{C}, \mathrm{N})$. dSOC is the change in soil organic carbon. Molecular weights and global warming potentials use values from the Fourth Assessment Report (IPCC, 2007).

\begin{tabular}{llll}
\hline From units & To units & $\begin{array}{l}\text { Molecular weights } \\
\text { conversion }\end{array}$ & $\begin{array}{l}\text { Global warming } \\
\text { potentials 100 years }\end{array}$ \\
\hline $\mathrm{kgC}(\mathrm{dSOC})$ & $\mathrm{kg} \mathrm{CO}$ eq. & $\mathrm{kgC} \times 44 / 12$ & 1 \\
$\mathrm{kgC}\left(\mathrm{CH}_{4}\right)$ & $\mathrm{kg} \mathrm{CO}$ eq. & $\mathrm{kgC} \times 16 / 12$ & 21 \\
$\mathrm{~kg} \mathrm{~N}\left(\mathrm{~N}_{2} \mathrm{O}\right)$ & $\mathrm{kg} \mathrm{CO}$ eq. & $\mathrm{kg} \mathrm{N} \times 44 / 28$ & 310 \\
\hline
\end{tabular}

Wood harvesting data consisted of five layers: (1) roundwood forest area in hectares for each cell, (2) fuelwood forest area in hectares for each cell, (3) roundwood (industrial) harvest volume in cubic metres, (4) fuelwood harvest volume in cubic metres, and (5) total harvest volume (roundwood + fuelwood) in cubic metres. We chose fuel and industrial roundwood harvest $\left(\mathrm{m}^{3}\right)$ as our harvest data. Wood harvest is a gross flux since no regrowth is considered. We assumed instantaneous emissions assigned to the place of removal, without considering lags in decay, the fate of the harvested product (i.e. slash, paper, furniture, construction), or the possible substitution effects (e.g. energy production using wood biomass instead of fossil fuels). We therefore acknowledge that the instantaneous flux from wood harvest would be lower if these effects had been considered. Emissions were transformed from square metres to $\mathrm{MgCO}_{2} \mathrm{yr}^{-1}$ using an emission factor of $0.25\left(\mathrm{Mg} \mathrm{Cm}^{-3}\right.$; Grace et al., 2014) and a C to $\mathrm{CO}_{2}$ factor shown in Table 1. The resolution of this layer was larger than our grid, so wood estimates were equally distributed among our $0.5^{\circ}$ grid cells. Because wood harvesting relied on official data reported by countries to FAO, the authors assumed that harvesting emissions only derive from forests that remain as forests (legal logging) and assigned these emissions to forested areas only. Figure S3 (in the Supplement) shows different spatial locations for deforestation and wood harvesting emissions. However, this assumption may be wrong and some imprecise amount of double counting may occur. Uncertainties were not estimated in the original harvest emission data. Therefore, and based on the authors' expert opinion, we chose a $20 \%$ uncertainty value, per pixel.

\subsubsection{Cropland soils (USEPA, 2013)}

Cropland emissions $\left(\mathrm{N}_{2} \mathrm{O}\right.$ and soil dSOC; changes in soil organic carbon) were produced by Ogle (2013), for the Environmental Protection Agency MAC-Report (USEPA, 2013), at $0.5^{\circ}$ resolution for time periods in 2000-2030 with 5year increments, based on the DAYCENT ecosystem model (Ogle et al., 2007). For our AFOLU analysis we used the annual mean emission data for the period 2000-2005. The original units $\left(\mathrm{g} \mathrm{N}_{2} \mathrm{O}-\mathrm{N} \mathrm{m}^{-2} \mathrm{yr}^{-1}\right.$ and $\left.\mathrm{g} \mathrm{C} \mathrm{m}^{-2} 5 \mathrm{yr}^{-1}\right)$ were transformed to $\mathrm{CO}_{2} \mathrm{e} \mathrm{yr}^{-1}$ grid cell $^{-1}$ (Table 1). The original dataset included direct and indirect emissions from mineral- based cropland soil processes: synthetic and organic fertilization, residue $\mathrm{N}$, mineralization, and fixation. To be consistent with other data sets we did not include indirect emissions (e.g. $\mathrm{NO}_{3}^{-}$leaching, $\mathrm{N}$ runoff in overland water flow). Emissions estimated by the DAYCENT include soil and litter pools and focus on six major crop types (maize, wheat, barley, sorghum, soybean, and millet), excluding other important tropical crops (sugar, coffee, cacao, cotton, tobacco, etc.). As a result, the cropland area simulated by DAYCENT was about $61 \%$ of the global non-rice cropland areas reported by FAOSTAT, which resulted in lower cropland emissions when compared to other databases (e.g. FAOSTAT and EDGAR). Moreover, due to the known poor performance of the DAYCENT model over organic soils, cropland emissions over drained histosols were not part of the estimated emissions. Uncertainties were offered per pixel $\left(0.5^{\circ}\right)$ as standard deviations per dSOC and $\mathrm{N}_{2} \mathrm{O}$ separately. Final $\mathrm{CO}_{2} \mathrm{e}$ uncertainties per pixel were propagated as independent data using the squared root of the summed variances. To complement the emission gap from the organic cultivated soils, we used a Tier 1 approach that relied on the location of the tropical areas of histosols (the International Soil Reference and Information Center (ISRIC)'s global soil database), the location of cropland areas per crop types (Monfreda et al., 2008), and a Tier 1 annual emission factor for cultivated organic soils (20 Mg Cha ${ }^{-1} \mathrm{yr}^{-1}$ ) derived from the IPCC (IPCC, 2006; Supplement).

\subsubsection{Paddy rice (USEPA, 2013)}

We used data from Li (2013), from the USEPA's MAC Report (2013). Emissions were estimated by the DenitrificationDecomposition (DNDC) model, which simulates production, crop yields, greenhouse gas fluxes $\left(\mathrm{CH}_{4}, \mathrm{~N}_{2} \mathrm{O}\right)$, and soil organic carbon (dSOC) of global paddy rice, at $0.5^{\circ}$ resolution under "business-as-usual" (BAU) conditions and various mitigation strategies as explained in $\mathrm{Li}$ et al. (2001, 2006). This model includes soil, litter, and above- and belowground biomass as main carbon pools. Model outputs were reported for 2010 as the baseline and used 22 years of replications to account for climate variability. The original units ( $\mathrm{kg} \mathrm{Cha}^{-1} \mathrm{yr}^{-1}$ for dSOC and $\mathrm{CH}_{4}$ and $\mathrm{KgNha}^{-1} \mathrm{yr}^{-1}$ for $\mathrm{N}_{2} \mathrm{O}$ ) were re-projected to equal-area values and transformed to $\mathrm{CO}_{2} \mathrm{e}$ (Table 1). Emissions were estimated using the MSF (most sensitive factor) method which relies on an envelope approach and estimates maximum and minimum emissions based on extreme soil properties. No mean values were offered. The distribution of the data were known to be rightskewed, and through the authors' expert judgement a lognormal approach was considered to be the best - although not perfect - fit from where to estimate the mean (50th percentile) and maximum and minimum (10th and 90th percentile) for each cell. 


\subsubsection{Livestock (Herrero et al., 2013)}

Livestock emission data includes enteric fermentation $\left(\mathrm{CH}_{4}\right)$ and manure management $\left(\mathrm{N}_{2} \mathrm{O}, \mathrm{CH}_{4}\right)$ for the year 2000 for 28 regions, 8 livestock production systems, 4 animal species (cattle, small ruminants, pigs, and poultry), and 3 livestock products (milk, meat, and eggs) at $0.1^{\circ}$ cell resolution. The $\mathrm{CO}_{2} \mathrm{e}$ of enteric fermentation and manure management was then summed to obtain a total emission value of livestock per grid cell. Since no spatially explicit uncertainty data were provided, and based on the authors' expert judgement, we applied a $20 \%$ value for livestock emissions per cell and per gas. Per cell livestock GHG uncertainties were estimated by square rooting the sum of their variances.

\subsubsection{Other AFOLU databases}

\section{FAOSTAT database}

This covers agriculture and Forestry and Other Land Uses (FOLU) and their associated emissions of $\mathrm{CO}_{2}, \mathrm{CH}_{4}$, and $\mathrm{N}_{2} \mathrm{O}$, following IPCC 2006 Guidelines at Tier 1 (Tubiello et al., 2014). Emissions are estimated for nearly 200 countries for the reference period 1961-2012 (agriculture) and 1990-2012 (FOLU), based on activity data submitted to and collated by FAO. FAOSTAT includes estimates of emissions from biomass fires, peatland drainage, and fires, based on geospatial information, as well as on forest carbon stock changes (both emissions and absorptions) based on nationallevel FAO Forest Resources Assessment data (FRA, 2010). FOLU carbon balances in FAOSTAT are emissions from afforestation, reforestation, degradation, regrowth, and harvest activities. The FAOSTAT emission estimates are based on annual FAO emissions updates for AFOLU (Tubiello et al., 2014).

\section{EDGAR database}

EDGAR provides global GHG emissions from multiple gases $\left(\mathrm{CO}_{2}, \mathrm{CH}_{4}, \mathrm{~N}_{2} \mathrm{O}\right)$ at $0.1^{\circ}$ and country levels. It covers all IPCC sectors (energy, industry, waste management, and AFOLU), mainly applying IPCC 2006 guidelines for emission estimations (EDGAR, 2012). We selected EDGAR's 4.2 Fast Track 2010 (FT 2010) data. Emissions cover the period 2000-2010 on an annual basis at the country level and are offered as gigagrams of gas. No uncertainties are provided. Transformation to $\mathrm{CO}_{2} \mathrm{e}$ used the Fourth Assessment Report (AR4) 100-year global warming potential values to be consistent with other datasets. Metadata can be found at EDGAR (2012), although further transparency and more complete documentation are required for this database.

\subsection{Methods}

\subsubsection{Hotspots dataset}

Our AFOLU assessment is based on several assumptions. We focus on human-induced gross emissions only, excluding sinks. We exclude emissions and sinks from unmanaged land (e.g. $\mathrm{CH}_{4}$ or $\mathrm{N}_{2} \mathrm{O}$ emissions from unmanaged natural wetlands). We focused on direct gross emissions excluding indirect emissions whenever possible (e.g. indirect emissions from nitrate leaching and surface runoff from croplands). Delayed fluxes (legacies) are important (e.g. underestimations of up to $62 \%$ of the total emissions when recent legacy fluxes are excluded; Houghton et al., 2012) but are frequently omitted in GHG analyses that derive from remote sensing, such as our deforestation emissions from Harris et al. (2012). Wood harvesting emissions also excluded legacy fluxes. Therefore, no forest regrowth of cleared, burned, or disturbed forests is included in our AFOLU 2000-2005 assessment. Other important components of the overall terrestrial and carbon balance, such as changes in litter, coarse woody debris, and soil carbon, are also not part of the emissions from deforestation and wood harvesting, since these pools were not considered in the original datasets (see Table S2, Supplement). For the other land uses - fire, agricultural soils, and paddy rice their emission models (e.g. CASA, DAYCENT, and DNDC) included temporal spin-ups to guarantee the stability of the emissions for their temporal scales under analysis. Certain legacies have, therefore, been considered (please see references for further details on these models). In the case of fires, since $90 \%$ of tropical fires are the result of human activity (Román-Cuesta et al., 2013; Van der Werf et al., 2010), we assumed all emissions to be human-induced, independently of whether they are climate-driven. This may have resulted in some overestimation of fire emissions in drier ecosystems where lightening may start the fires (e.g. African woodlands). However, since we have excluded deforestation fires (to avoid double counting with deforestation) and we have also excluded savannah and agricultural fires (under the assumption of carbon neutrality), we are quite certain that our gross fire emissions for 2000-2005 are rather conservative. As requested by the IPCC (Federici et al., 2016), we have included all biomass burning emissions without considerations of climate extremes, even though we acknowledge the role of increased frequencies and intensities of droughts and their interaction with fire in human-disturbed landscapes in the tropics (Brando et al., 2014). We assumed instantaneous emissions of all carbon that is lost from the land after human action (Tier 1, IPCC, 2006; e.g. fire, deforestation, and wood harvesting), with no transboundary considerations (e.g. the emissions are assigned wherever the disturbance takes place, particularly important for the harvested wood products). Life-cycle substitution effects are not considered for harvested wood (Peters et al., 2012). 


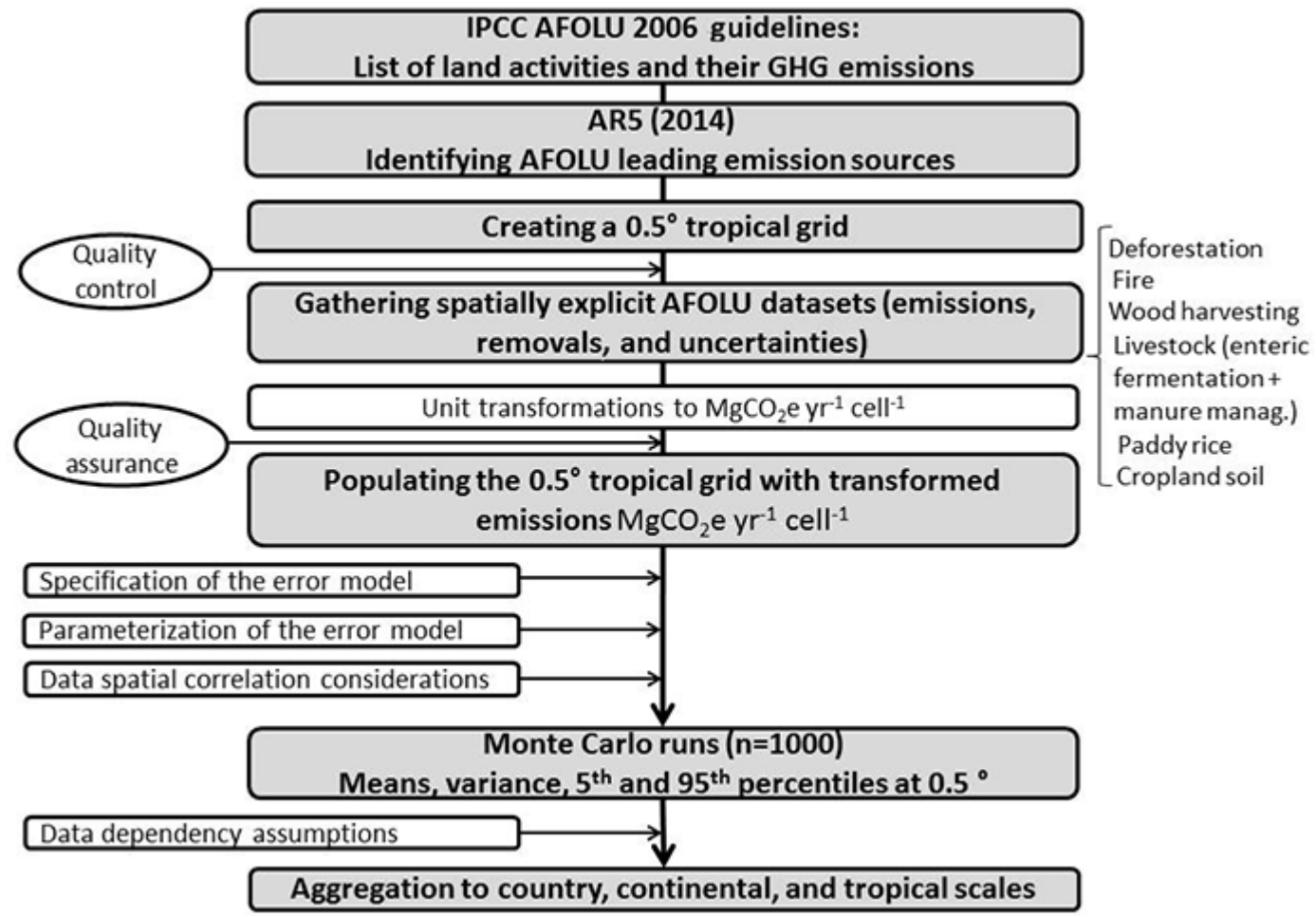

Figure 1. Methodological framework used to estimate the aggregated AFOLU emissions (annual means) and associated uncertainties (variance, 5th, 95 th percentiles) at $0.5^{\circ}$ resolution, for 2000-2005.

Figure 1 describes the steps followed to produce our spatially explicit layers of gross AFOLU emissions and uncertainties. We first assessed all possible emissions, land uses, and human activities under the framework of the IPCC (2006) AFOLU guidelines. We then selected the key AFOLU emissions sources as identified in the IPCC Fifth Assessment Report (AR5; Smith et al., 2014). There were seven key emission sources: three within the forest sector (deforestation, fire, and wood harvesting (these last two were considered as forest degradation)) and four within agriculture (cropland soils, paddy rice, enteric fermentation, and manure management (aggregated as livestock)). We chose 100year global warming potentials as provided in AR4 (IPCC, 2007; Table 1) because all emission datasets were prior to the launching of AR5. We have preserved their choice to be consistent with their published estimates and with emissions that could not be reproduced. To promote the spatial assessment, we produced an empty grid with cells of $0.5^{\circ} \times 0.5^{\circ}$ in a World Geographical reference System (WGS-84, lat-long). To correct for the unaccounted Earth distortions that come with a geographical system we used equal-area re-projected values whenever we needed area-weighted estimates of the emissions. This grid was then populated with the seven emission sources, unit transformed, quality controlled, and assessed (see Supplement). We used Monte Carlo simulations to aggregate the gross AFOLU emissions and their uncertainties and produced four final estimates per cell: mean annual

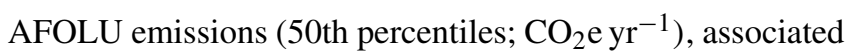
variance, and 5th and 95th confidence intervals. Data were then aggregated to continental and tropical scales. When aggregating uncertainties at the pixel level, we assumed emission sources to be mutually uncorrelated. However, when the aggregation of the uncertainties included a change in spatial support (e.g. pixel to continental or pixel to tropical), we assumed data complete dependence, which offered a conservative (worst-case) scenario approach for the final aggregated uncertainties (see Supplement for further information). To understand which emission sources (e.g. deforestation, degradation, livestock, paddy rice) contributed the most to the final uncertainties on the continental scale, we used the variance data produced per pixel and aggregated them using the dependence assumption expressed above. The attribution of the uncertainty was then estimated as percentages of the final aggregated variance for each emission source.

\subsubsection{Database comparison}

We contrast our hotspots of gross AFOLU emissions with the FAOSTAT and EDGAR databases. We run the comparisons at the country level and produce the estimates selecting the same countries, years, emission sources, assumptions (e.g. carbon neutrality of grasslands and agricultural waste), and rules (e.g. only direct emissions) to guarantee comparability. 


\section{Results and discussion}

\subsection{AFOLU hotspots of emissions and uncertainties}

Tropical AFOLU hotspots were located on all continents but spatially concentrated in a few areas only, with $25 \%$ of the tropical area responsible for $70 \%$ of the tropical AFOLU emissions (Fig. 2a). Gross fluxes reached values of up to $90 \mathrm{Mg} \mathrm{CO}_{2} \mathrm{e} \mathrm{ha}^{-1} \mathrm{yr}^{-1}$ in the hotspots, with Brazil, India, Indonesia, Democratic Republic of Congo, Angola, Central African Republic, Mozambique, Zambia, Malaysia, Sudan, and Bangladesh as the major contributors of tropical AFOLU emissions.

Hotspots were mainly led by forest emissions, both by deforestation and degradation, with large hotspots over humid rainforests in the arch of deforestation in Brazil and over the miombo-mopane dry forests of Africa. Deforestation and peatland fires were important in Indonesia, combined with agricultural hotspots from livestock and paddy rice. Agricultural emissions contributed less to the hotspots, with Asia, particularly India and Bangladesh, as main emitting regions with different relative contributions from livestock, paddy rice, and cropland emissions (Fig. 3). Southern Brazil, northern Argentina, and southeastern Paraguay also showed agricultural hotspots, mainly related to livestock. Main GHGs followed these patterns, with $\mathrm{CO}_{2}$ dominating the emissions from forest activities, turning this gas into the main target for mitigation action. $\mathrm{CH}_{4}$ dominated rice and livestock emissions, while $\mathrm{N}_{2} \mathrm{O}$ explained high cropland emissions (Fig. 4).

Emissions uncertainties were the highest for the hotspot regions, reaching values of up to $30 \%$ of the mean AFOLU emissions (Fig. 2b), which is lower than the reported uncertainties for global AFOLU values (e.g. 50\%; Smith et al., 2014). The coincidence of high AFOLU emissions and high uncertainties is not surprising since the emissions from the hotspots were led by forests, and forests host the largest emission uncertainties, in particular humid tropical forests undergoing deforestation, such as in Brazil and Indonesia, and forests with high fire emissions, such as dry miombo ecosystems in Africa or peatlands in Asia. Deforestation has long been identified as a main source of emissions uncertainties in the tropics due to the combined effect of uncertain areas and uncertain carbon densities (Houghton, 2010; Baccini et al., 2012; Houghton et al., 2012). High uncertainties in fire emissions relate to biomass, burned soil depths, and combustion completeness, which are the most uncertain components of the fire emission model of Van der Werf et al. (2010). Consequently, equatorial Asia and the African continent were the regions with the largest fire uncertainties of the globe (Van der Werf et al., 2010; Fig. S5).

Areas with high gross emissions that also host high uncertainties (e.g. forests) complicate the effectiveness of the mitigation action. Thus, while these areas have higher mitigation potentials (e.g. high emissions that could potentially be reduced), their uncertainties affect the reliability of their emissions estimates and, therefore, the effectiveness to implement actions to stabilize atmospheric GHGs (Grassi et al., 2008). For this reason, from a climate mitigation perspective and without economic or technical considerations, optimal mitigation scenarios should rather focus on areas with large gross fluxes and low(er) uncertainties. These areas would include agricultural hotspots (croplands, paddy rice, and livestock) without much contribution from forest emissions such as parts of India, Southeastern Brazil, northern Argentina, and central and southern Africa (southern DR Congo, Zambia, Angola; Fig. 5). Carter et al. (2015) determined that agricultural intensification and the use of available non-forest land offer opportunities for agricultural mitigation of up to $1 \mathrm{PgCO}_{2} \mathrm{e}$. This value coincides with sectorial analyses of mitigation targets for 2030 that would keep agricultural emissions in line with the $2^{\circ}$ target (Wollenberg et al., 2016). However, food security and economic development in countries with agrobusinesses make supplybased agricultural mitigation challenging (Smith et al., 2008, 2013). Moreover, as discussed in Wollenberg et al. (2016), more transformative technical and policy options will be needed to help agriculture achieve this $1 \mathrm{Pg} \mathrm{CO}_{2} \mathrm{e}$ target. Mitigation in the agricultural sector is further complicate by being technically more complex and more expensive than forest mitigation (USEPA, 2013; Smith et al., 2014). For these reasons, and in spite of their higher uncertainties, forests still remain high on the mitigation agenda, as recently seen in the Paris Agreement, associated COP decisions, and the New York Declaration on Forests.

\subsection{Tropical AFOLU emissions}

AFOLU data from the AR5 (e.g. Fig. 11.2 in Smith et al., 2014) show how the tropics have contributed with $\geq 70 \%$ of the global AFOLU emissions in the last decades, making this region the right place to search for hotspots of land use emissions. Our aggregated gross AFOLU emissions estimates of 8.0 (5.5-12.2) $\mathrm{Pg} \mathrm{CO}_{2} \mathrm{e} \mathrm{yr}^{-1}$ were in the range of other gross estimates for the same region and time period: 8.4 and 8.0 $\mathrm{Pg} \mathrm{CO}_{2} \mathrm{e} \mathrm{yr}^{-1}$ for FAOSTAT and EDGAR respectively (Table 2).

In spite of this good agreement, databases disagreed on the relative contribution of the leading emissions sources (Fig. 6). Forests emissions showed the largest divergences, particularly forest degradation (fire and wood harvesting emissions). This outcome was expected since forest emissions were responsible for $\geq 70 \%$ of the tropical gross AFOLU emissions in all the databases (Table 2). Gross degradation emissions - rather than deforestation - led the forest emissions in our AFOLU gross emissions (39\% vs. $36 \%$ of the tropical emissions respectively; Table 2), with a degradation to deforestation emission ratio of $108 \%$, reinforcing the great importance of reducing degradation for effective mitigation. Ratios above $100 \%$ for gross degradation vs. deforestation had already been reported by Houghton 

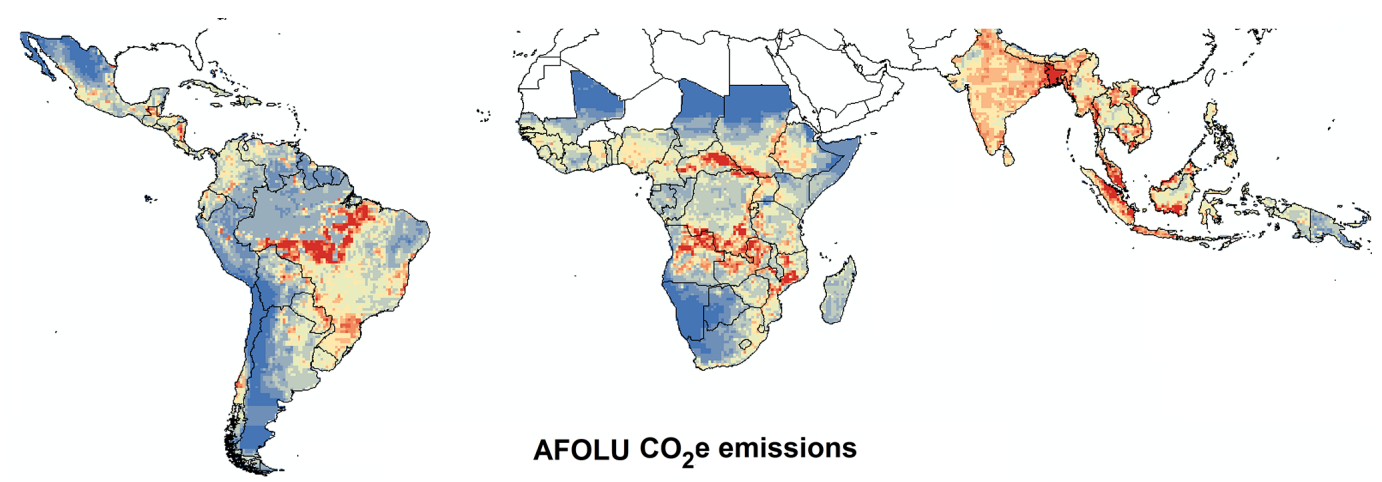

(a)

AFOLU $\mathrm{CO}_{2}$ e emissions
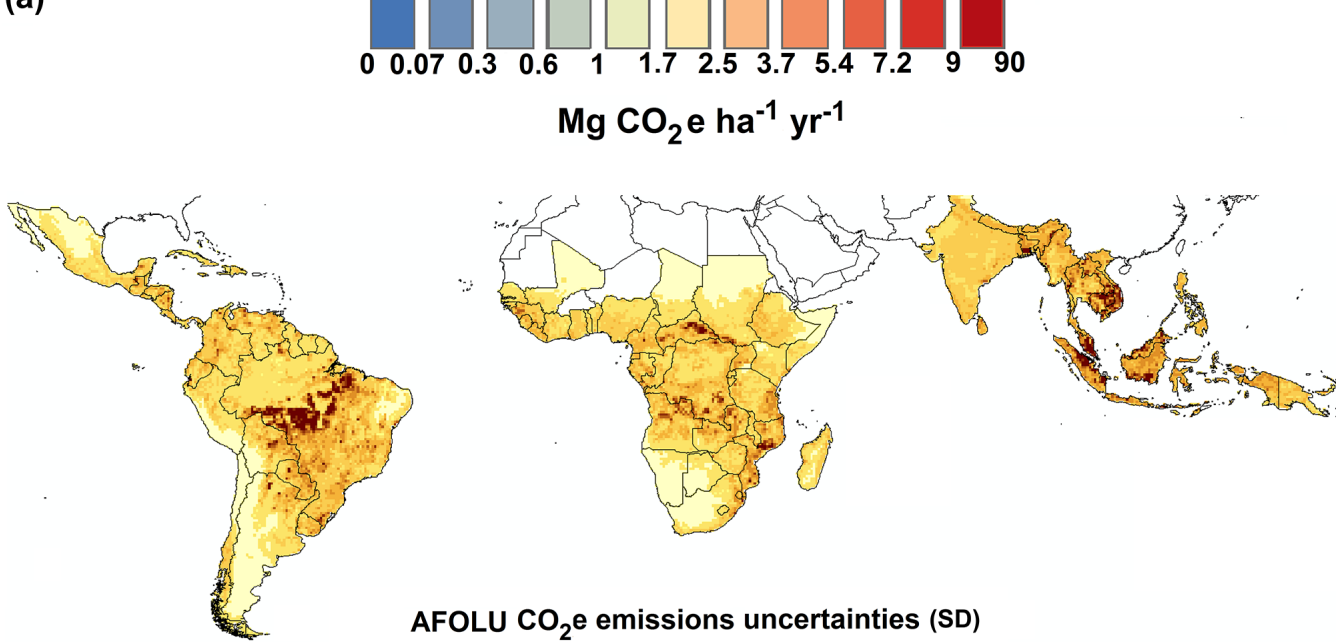

(b)

AFOLU $\mathrm{CO}_{2}$ e emissions uncertainties (SD)

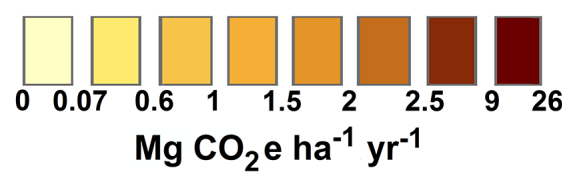

Figure 2. (a) Hotspots of annual AFOLU emissions (red cells) and (b) associated uncertainties (1 $\sigma$ ) in $\mathrm{Mg} \mathrm{CO}_{2} \mathrm{e} \mathrm{ha}^{-1} \mathrm{yr}^{-1} \mathrm{for}_{\mathrm{the}}$ tropical region, for the period 2000-2005, at $0.5^{\circ}$ resolution. Emissions are the result of 1000 Monte Carlo simulations for the leading AFOLU emission sources (deforestation, degradation (fire, wood harvesting), soils (crops, paddy rice), livestock (enteric fermentation and manure management).

et al. (2012) and Federici et al. (2015). Lower ratios have been observed in smaller areas (e.g. $40 \%$ Amazon, $47 \%$ Peruvian Amazon; Asner et al., 2010; Berenguer et al., 2014) or when the ratio focuses on net fluxes of degradation (e.g. $25-35 \%$ of the net land cover change flux if wood harvesting and shifting cultivation were not considered and an extra $11 \%$ over the net land cover change flux when excluding peatland fire emissions in Southeast Asia alone; Houghton et al., 2012).

In our hotspots analyses, fire led forest degradation in the tropics with almost a quarter (24.6\%) of the gross AFOLU emissions. Since we had excluded deforestation fires, most of our fire emissions relate to woodlands and forest degradation. Their exclusion or incomplete inclusion would therefore result in large emission omissions in gross AFOLU assessments, and their management is key for reducing tropical emissions. Fire degradation emissions are recurrently omitted in global AFOLU assessments under the assumption of carbon neutrality of the affected burned areas (e.g. whatever carbon is emitted through fire will be fixed again by regrowth and recovery; Houghton et al., 2012; Le Quéré et al., 2014; Canadell and Schulze, 2014; Smith et al., 2014). This assumption does not consider current evidence of nonsteady states after fire due to climatic pressures, humanized landscapes (fragmented, multi-disturbed), and increased frequencies of fires (Cochrane et al., 1999; Roman-Cuesta et al., 2014; Alencar et al., 2011, 2015; Brando et al., 2014; Oliveras et al., 2014; Pütz et al., 2014). Halted successional pathways and vegetation shifts represent a large, yet unknown proportion of the burned forest ecosystems in the tropics that require further research. Recent estimates suggest that postfire carbon recoveries in the Amazon are leading to degrada- 

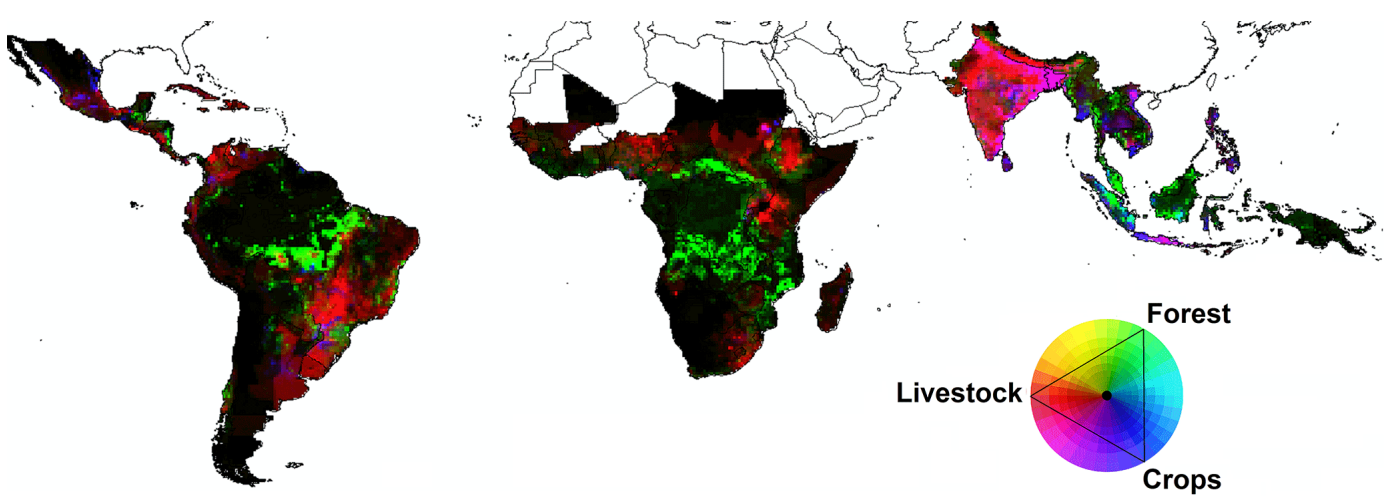

Figure 3. Contribution of the leading emission sources in percent of total emissions (grouped into forests, crops, and livestock) to the per pixel $\left(0.5^{\circ}\right)$, for 2000-2005. Forest emissions include fire, deforestation, and wood harvesting. Crops emissions includes paddy rice, cropland soil, and croplands over drained histosols. Livestock includes enteric fermentation and manure management emissions. This figure is a red-green-blue (RGB) image where final colours represent the strength of the emissions for the three sources (e.g. fuchsia colours in Asia represent equal emissions from livestock (red) and crops (blue). Dark represent areas of low emissions.

tion emissions of the order of $46 \pm 29.9 \mathrm{Mg} \mathrm{Cha}^{-1}$ (Balch et al., 2016).

In spite of our uncomplete knowledge of forest postdisturbance recovery pathways (e.g. poorly understood processes, omitted emissions, missing pools, unconsidered GHGs), the importance of the forest sector for mitigation action is evidenced by the large amount of countries explicitly mentioning it in their NDCs (60\%; Grassi et al., 2015). Moreover, countries count on financial support to minimize their forest emissions and enhance their sinks, on a national scale, through the REDD + mechanism, which has now become part of the Paris Agreement (Climate Focus, 2015).

In the agricultural sector, our emissions reached estimates of 1.9 (1.5-2.5) $\mathrm{Pg} \mathrm{CO}_{2} \mathrm{e} \mathrm{yr}^{-1}$, in the range of the other databases (2.5 and 2.1 $\mathrm{PgCO}_{2} \mathrm{e} \mathrm{yr}^{-1}$ for FAOSTAT and EDGAR respectively). These values, represent a relatively small part of the AFOLU emissions in the tropics (25-30\%), but an attribution of the forest emissions to their drivers would highlight the importance of agriculture as the main engine behind tropical forest loss and emissions. Thus, for the period 1980-2000, $83 \%$ of the agricultural expansion in the tropics was at the expense of forests (Gibbs et al., 2010), calling for integrated mitigation programmes that simultaneously include forestry and agriculture (Carter et al., 2015). Our agricultural estimates represented only ca. half of the agricultural emissions reported globally for 20002009 (5-6 $\mathrm{Pg} \mathrm{CO}_{2} \mathrm{e} \mathrm{yr}^{-1}$; Smith et al., 2014; Tubiello et al., 2015). This highlights the major role of agriculture in nontropical countries and emergent economies like China, although agricultural emissions are rising faster in developing countries than in developed ones (Smith et al., 2014). The agricultural sector is the largest contributor to global anthropogenic non- $\mathrm{CO}_{2}$ GHGs, accounting for $56 \%$ of emissions in 2005 (USEPA, 2013). Enteric fermentation and agricultural soils are globally the main sources of agricultural emis- sions (Smith et al., 2014) and show a strong rising trend since the $70 \mathrm{~s}$ ( $1 \%$ per decade) due to increases in animal heads and the use of synthetic fertilizers (Tubiello et al., 2015). Areas with growing emission trends are attractive for land-based mitigation action, and countries are engaging in agricultural mitigation in their NDCs through climate-smart initiatives (Richards et al., 2015). However, more transformative technical and policy options and higher level of financial support will be needed for further achievements in this sector (Wollenberg et al., 2016). The most prominent agricultural mitigation practices include improved cropland and grazing land management, restoration of degraded lands, and cultivated organic soils. Lower, but still significant mitigation potential is provided by water and rice management, livestock and manure management, set-aside, land use change, and agroforestry (Smith et al., 2008).

In terms of gases, $\mathrm{CO}_{2}$ led the AFOLU emissions in the tropics with ca. $70 \%$ of the tropical emissions (5.5 (3.39.5) $\mathrm{Pg} \mathrm{CO}_{2} \mathrm{e} \mathrm{yr}^{-1}$ (Table 2, Fig. 4)). The remaining non$\mathrm{CO}_{2}$ contribution (30\%) was mainly led by $\mathrm{CH}_{4}(1.5$ (1.11.9) $\mathrm{Pg} \mathrm{CO}_{2} \mathrm{e} \mathrm{yr}^{-1}$ ) due to livestock and rice. Non- $\mathrm{CO}_{2}$ emissions from biomass burning $\left(\mathrm{N}_{2} \mathrm{O}\right.$ and $\left.\mathrm{CH}_{4}\right)$ represented 15 $34 \%$ of the $\mathrm{CO}_{2}$ emissions in the tropics (Table 2). These values reinforce the need to run multi-gas assessments $\left(\mathrm{CO}_{2}\right.$, $\mathrm{CH}_{4}, \mathrm{~N}_{2} \mathrm{O}$ ) for the AFOLU sector in order to gain a more coherent understanding of how the land affects the atmospheric composition and forces the climate. Thus, while temperature rises by around the end of this century will relate to the total emissions of long-lived greenhouse gases between 2000 and 2100 (e.g. $\mathrm{CO}_{2}$; Anderson, 2012) recent research concludes that the cumulative warming capacity of concurrent biogenic $\mathrm{CH}_{4}$ and $\mathrm{N}_{2} \mathrm{O}$ emissions is about a factor of 2 larger than the cooling effect resulting from the global land $\mathrm{CO}_{2}$ uptake in the 2000s (Tian et al., 2016). This results in a net positive cumulative impact of the three GHGs on the planetary 

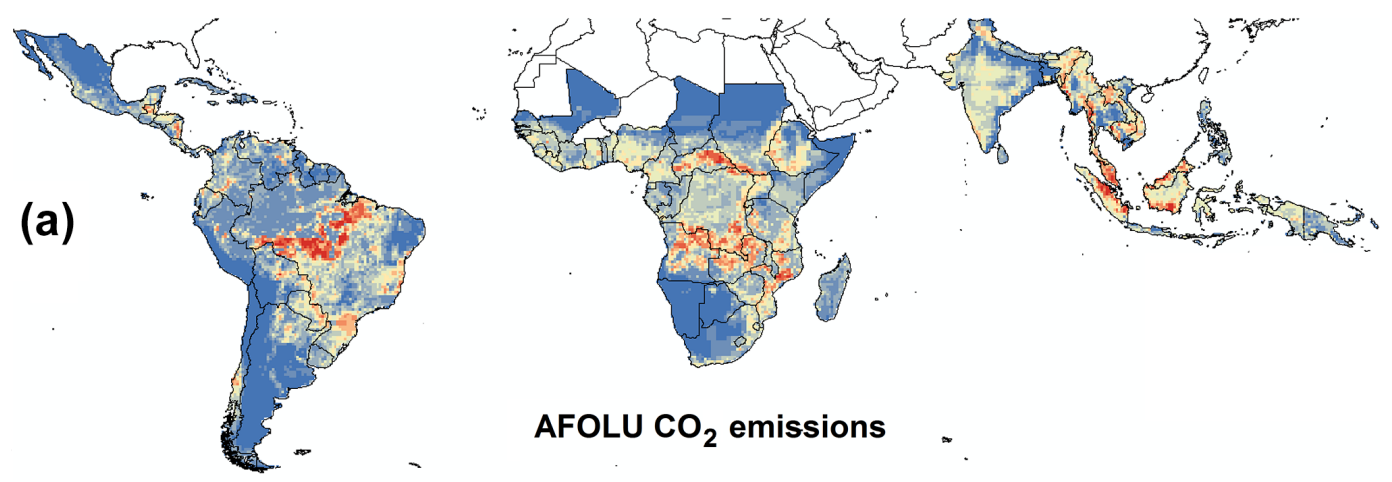

AFOLU $\mathrm{CO}_{2}$ emissions .
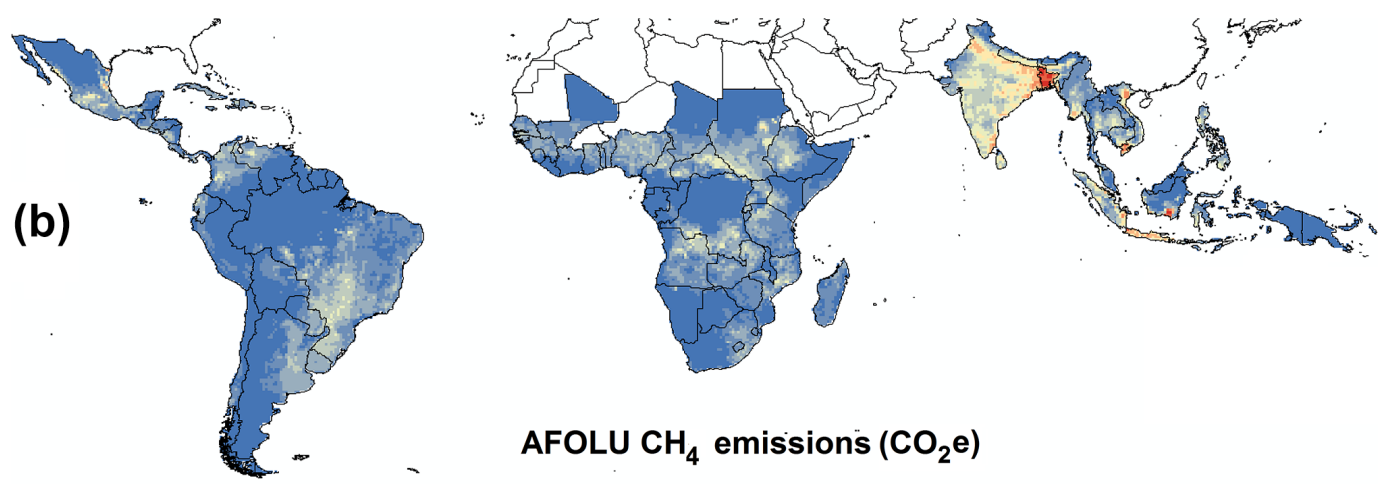

AFOLU $\mathrm{CH}_{4}$ emissions $\left(\mathrm{CO}_{2} \mathrm{e}\right)$
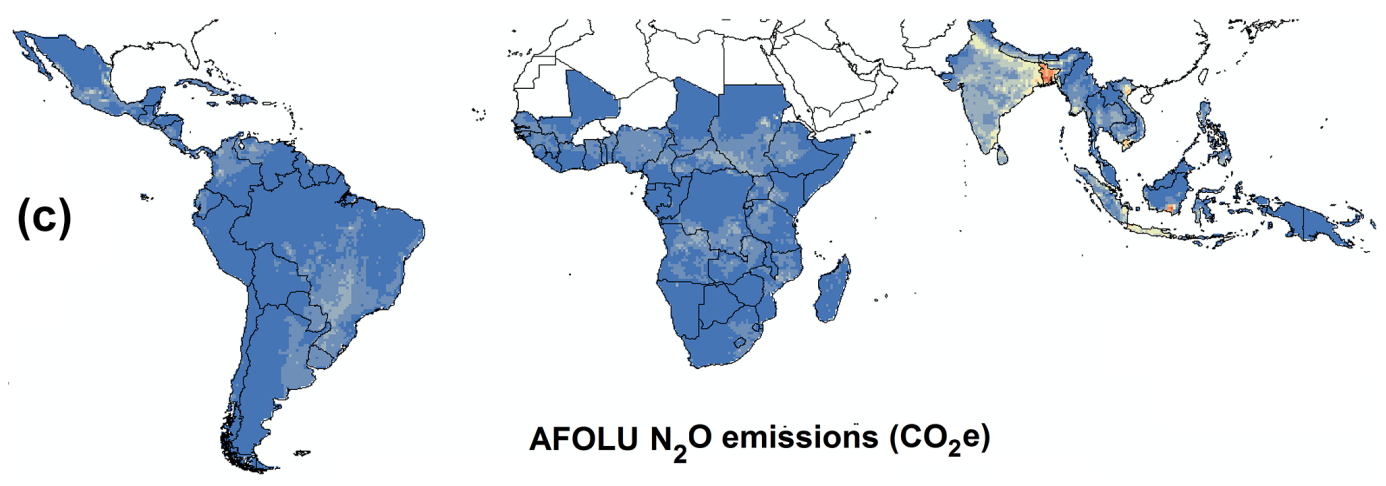

AFOLU $\mathrm{N}_{2} \mathrm{O}$ emissions $\left(\mathrm{CO}_{2} \mathrm{e}\right)$

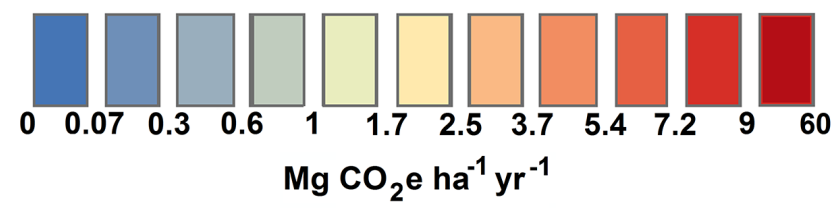

Figure 4. Mean annual AFOLU emissions $\left(\mathrm{MgCO}_{2} \mathrm{eha}^{-1} \mathrm{yr}^{-1}\right)$, for the period 2000-2005, disaggregated by greenhouse gases: (a) $\mathrm{CO}_{2}$ emissions, which are a proxy of forest emissions, (b) $\mathrm{CH}_{4}$, and (c) $\mathrm{N}_{2} \mathrm{O}$ emissions, which are proxies of agricultural emissions. Emissions are the result of 1000 Monte simulations for the leading AFOLU emission sources considered.

energy budget, which calls for shorter-term mitigation initiatives (Tian et al., 2016).

On the aggregated tropical scale, uncertainties were higher (up to $50 \%$ of the mean emissions) than on the landscape scale $\left(0.5^{\circ} ; 30 \%\right)$, in line with other reports (Smith et al., 2014; Tubiello et al., 2015). The spatial scale of the emission assessments, therefore, influences the final uncertainties due to assumptions about the spatial correlation of the errors. Several authors have suggested the importance of working on more detailed spatial scales (e.g. $30 \mathrm{~m})$ to reduce the uncertainties, particularly of forest emissions, by having more accurate data on forest area changes and carbon densities (Houghton, 2005; Grassi et al., 2008; Asner et al., 2010; Baccini et al., 2012; Houghton et al., 2012). 
Table 2. Contribution of the different greenhouse gases $\left(\mathrm{CO}_{2}, \mathrm{CH}_{4}, \mathrm{~N}_{2} \mathrm{O}\right)$ to continental and tropical AFOLU annual mean gross emissions for the period 2000-2005 (in parenthesis are the 5th and the 95th percentiles of the aggregated AFOLU emissions). Contribution of the different leading emission sources and different GHGs to the tropical and continental AFOLU gross emissions (expressed as \% of emissions). Partitioning of the AFOLU emissions uncertainties among the leading emission sources and the considered GHG gases (expressed as \% of variance). AFOLU emissions are the result of 1000 Monte Carlo runs for the leading emission sources.

\begin{tabular}{|c|c|c|c|c|c|c|}
\hline \multicolumn{7}{|c|}{ 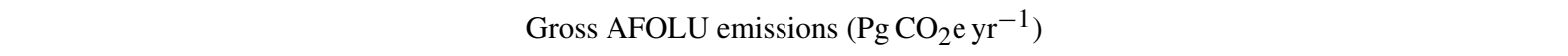 } \\
\hline & & $\mathrm{CO}_{2} \mathrm{e}$ & $\mathrm{CO}_{2}$ & $\mathrm{CH}_{4}$ & $\mathrm{~N}_{2} \mathrm{O}$ & \\
\hline Tropical & & $8.0(5.5-12.2)$ & $5.5(3.3-9.5)$ & $1.5(1.1-1.9)$ & $1(0.8-1.2)$ & \\
\hline Central \& South America & & $2.7(1.8-4.5)$ & $2.1(1.3-3.8)$ & $0.35(0.25-0.45)$ & $0.25(0.2-0.3)$ & \\
\hline Africa & & $2.8(1.9-4.0)$ & $2.1(1.4-3.2)$ & $0.39(0.27-0.5)$ & $0.3(0.22-0.39)$ & \\
\hline Asia & & $2.5(1.7-3.8)$ & $1.3(0.7-2.4)$ & $0.74(0.56-0.95)$ & $0.41(0.35-0.47)$ & \\
\hline \multicolumn{7}{|c|}{ Contribution of leading emission sources to the tropical AFOLU gross emissions ( $\%$ ) } \\
\hline & Deforestation & Fire & Rice & Wood harvesting & Livestock & Crops \\
\hline Tropical & 36.3 & 24.6 & 6.9 & 14.6 & 15 & 2.5 \\
\hline Central \& South America & 59.6 & 8.2 & 1.1 & 11.9 & 15.9 & 3.4 \\
\hline Africa & 15.2 & 52.6 & 0.3 & 20.3 & 11 & 0.7 \\
\hline Asia & 34.8 & 11.3 & 20.2 & 11.5 & 18.5 & 3.7 \\
\hline \multicolumn{7}{|c|}{ Contribution of leading emission sources to total uncertainty (\%) } \\
\hline & Deforestation & Fire & Rice & Harvesting & Livestock & Crops \\
\hline Tropical & 92.5 & 4.5 & 0.2 & 1.4 & 1.4 & 0.0 \\
\hline Central \& South America & 98.4 & 0.3 & 0.0 & 0.5 & 0.8 & 0.0 \\
\hline Africa & 69.8 & 25.5 & 0.0 & 3.7 & 1.1 & 0.0 \\
\hline Asia & 91.4 & 2.4 & 2.1 & 1.1 & 2.9 & 0.0 \\
\hline
\end{tabular}

Contribution of different gases to the tropical AFOLU gross emissions (\%)

\begin{tabular}{lllll}
\hline & $\mathrm{CO}_{2} \mathrm{e}$ & $\mathrm{CO}_{2}$ & $\mathrm{CH}_{4}$ & $\mathrm{~N}_{2} \mathrm{O}$ \\
\hline Tropical & & 69 & 19 & 12 \\
Central \& South America & 34 & 78 & 13 & 9 \\
Africa & 35 & 75 & 14 & 11 \\
Asia & 31 & 53 & 30 & 17 \\
\hline & Contribution of different gases to total uncertainty (\%) & 0.4 \\
\hline Tropical & & 98.3 & 1.3 & 0.1 \\
Central \& South America & 48 & 99.4 & 0.5 & 0.7 \\
Africa & 27.3 & 98.2 & 1.1 & 0.6 \\
Asia & 24.7 & 95.5 & 3.9 & \\
\hline
\end{tabular}

To better understand the uncertainty role of the different emission sources on the tropical aggregated scale, we ran a partitioning of the tropical uncertainty. We found a disproportional contribution of deforestation to the tropical uncertainty budget (92.5\%; Table 2), which agreed with the results from other researchers (Morton et al., 2011) but left the remaining emission sources with a surprisingly modest contribution to the final uncertainty $(7.5 \%)$. As was the case for the hotspots, untangling the relative contribution of the emission sources to the tropical uncertainty budget brings in trade-offs between prioritizing mitigation action on sources that are large emitters but are highly uncertain (e.g. deforestation is responsible for $36 \%$ of the emissions but carries al- most all the tropical emission uncertainty (92.5\%; Table 2)) or choosing emitters that contribute less to the total emissions but are more certain (e.g livestock contributed less to the tropical emissions $(15 \%)$ but had a very small part on the uncertainty budget (1.4\%; Table 2 ; Fig. 5)).

\subsection{Continental AFOLU emissions}

Continents contributed similarly to the tropical AFOLU gross emissions: 2.7 (1.8-4.5), 2.8 (1.9-4.0), and 2.5 (1.73.8) $\mathrm{Pg} \mathrm{CO}_{2} \mathrm{e} \mathrm{yr}^{-1}$ for Central and South (CS) America, Africa, and Asia respectively (Table 2). Area-weighted emissions would, however, turn Asia into the largest continental source, with a mean of $3.2 \mathrm{MgCO}_{2} \mathrm{eha}^{-1} \mathrm{yr}^{-1}$ 

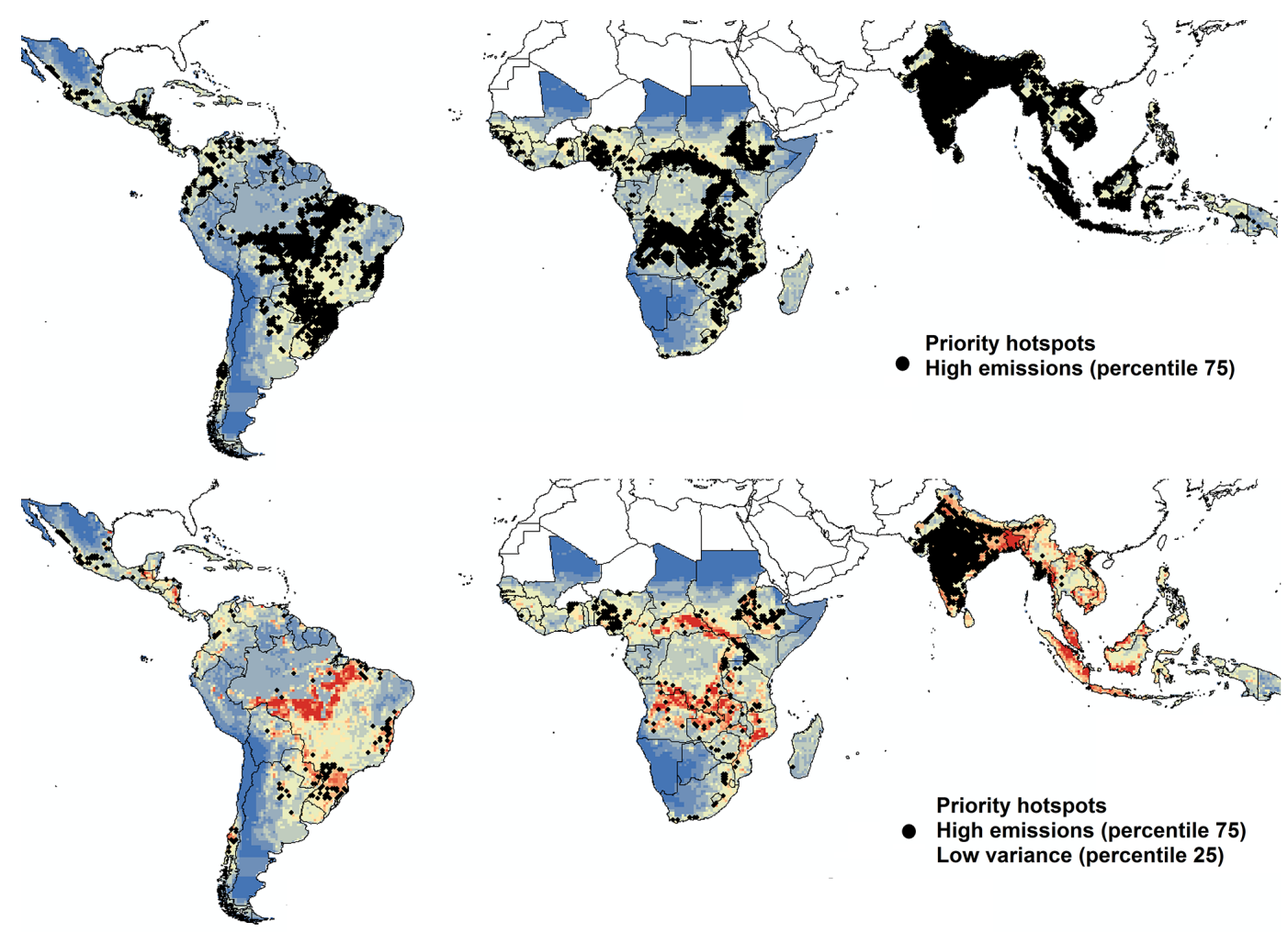

Figure 5. Identification of priority regions for mitigation in the AFOLU sector in the tropics for 2000-2005, considering mitigation potentials only (higher emissions, percentile 75) and the degree of certainty of these potentials (low uncertainties, percentile 25 of the variance). Economic feasibility would lead to different priority regions.

followed by Africa and CS America with 1.3 and $1.35 \mathrm{Mg} \mathrm{CO}_{2} \mathrm{e} \mathrm{ha}^{-1} \mathrm{yr}^{-1}$, each. The leading sources for the continental emissions disagreed among databases, but our hotspot research suggested that African emissions were dominated by fire in dry forests $(52.6 \%$ of the African emissions; Table 2), which fits Africa's description as "the fire continent" (Fig. 7; Mbow, 2014). Any effective mitigation action will therefore need to consider fire management, particularly in miombo dry forests and Sudano-Sahelian woodlands, which are the most affected forests and the largest contributors to emissions hotspots. Contrastingly, Central and South America were mainly led by deforestation ( $60 \%$ of the continental emissions) and forest degradation (20\%), mostly affecting humid forests. And while deforestation in Brazilian rainforests has since reduced, it has increased in dry forest in the region (e.g. the Chaco region in Argentina, Paraguay, and Bolivia; Hansen et al., 2013), and forest degradation has also increased (Brando et al., 2014; Federici et al., 2015). The Asian emissions were the most diverse and were similarly led by different sources: (i) paddy rice (Asia is the world's largest rice-producing region and is responsible for over $80 \%$ of the total CH4 emissions; USEPA, 2013); (ii) livestock activities (Tubiello et al., 2014); (iii) deforestation (Hansen et al., 2013); and (iv) fire over peatlands, particularly in Indonesia (Van der Werf et al., 2010; Gaveau et al., 2014; Table 2).
Moreover, the Asian continent has the peculiarity of emitting almost half of the tropical non- $\mathrm{CO}_{2}$ emissions $(47 \%$, Table 2), as observed by other authors (USEPA, 2013), and still has positively growing emission trends (Tubiello et al., 2014). Effective mitigation action on non- $\mathrm{CO}_{2}$ emissions is therefore key for Asian and global mitigation.

The partitioning of the tropical AFOLU uncertainty at a continental level showed that CS America contributed with half of the variance $(48 \%$, Table 2$)$, which was expected since the emissions of this continent are led by the most uncertain source (deforestation). Africa and Asia contributed similarly to the rest of the uncertainty (27.3 and $24.7 \%$ respectively). Based on the uncertainty of the emissions, mitigation investments in CS America would, therefore, be less effective than investing in Africa and Asia, particularly with regard to forests. Other considerations, such as technical and economic feasibilities, as well as the provision of ecological services would, however, retain forests as high-priority mitigation targets.

\section{Conclusions}

Our dataset offers novel landscape-scale information on the spatial distribution of hotspots of AFOLU gross emissions and their uncertainties, disaggregated by gases and by lead- 


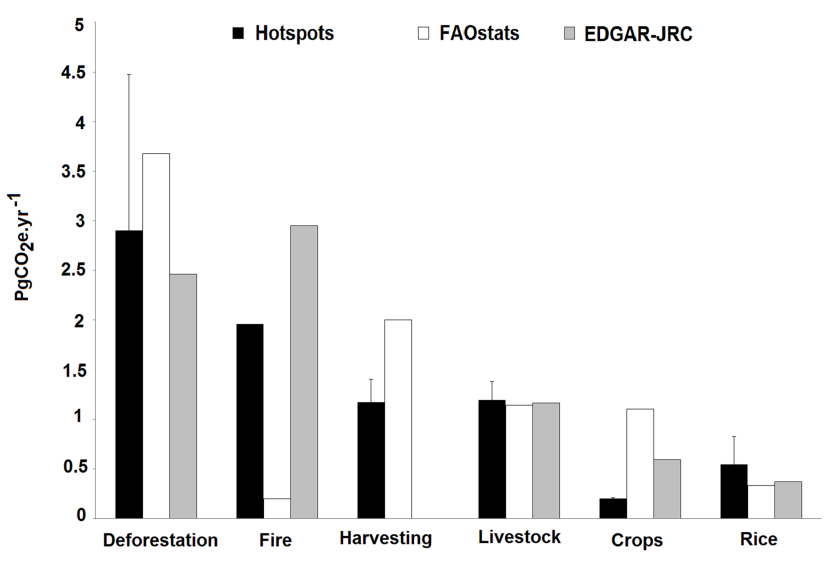

Figure 6. Distribution of mean annual emissions per sources of emissions for the three databases, in the tropics, for 2000-2005. Bars indicate uncertainty estimates for the hotspot database, and standard deviations for FAOSTAT and EDGAR estimated from country data variability since no uncertainty data exist for these two databases.

ing emission sources. This AFOLU analysis can be useful as a benchmark against which countries can assess their progress in reducing their AFOLU gross emissions in a comparable and comprehensive manner across the tropics. Moreover, assessments of gross emissions offer useful insights on potential drivers behind the emission sources, which can then lead to policies and measures to reduce these emissions through appropriate mitigation actions. Aggregated gross emissions at the country level are offered in the Supplement. Our data highlight the following: (i) the existence of AFOLU emissions hotspots on all continents, with particular importance of evergreen rainforest deforestation in Central and South America, fire in dry forests in Africa, and both peatland emissions and agriculture in Asia; (ii) a predominant contribution of forests and $\mathrm{CO}_{2}$ to the total AFOLU emissions $(69 \%)$ and to their uncertainties $(98 \%)$. Furthermore, (iii) higher gross fluxes from forests coincide with higher uncertainties, making agricultural hotspots appealing for effective mitigation action; however, (iv) agricultural non- $\mathrm{CO}_{2}$ emissions are much lower (ca. $25 \%$ of the total gross emissions in the tropics for 2000-2005) than forests, with livestock $(15.5 \%)$ and rice $(7 \%)$ leading the emissions. Gross AFOLU tropical emissions $8.0(5.5-12.2)$ were in the range of other databases 8.4 and $8.0 \mathrm{Pg} \mathrm{CO}_{2} \mathrm{e} \mathrm{yr}^{-1}$ (FAOSTAT and EDGAR respectively).

It is worth remarking that under gross emissions, sustainable wood harvesting and fires not leading to long-term declines in carbon storage would still be considered as hotspots of emissions since the subsequent recovery of carbon stocks is not considered. Moreover, gross emissions are not to be confused with the overall net land-to-atmosphere flux due to human land use because legacy effects and changes in litter and soil organic matter are not included. Independently

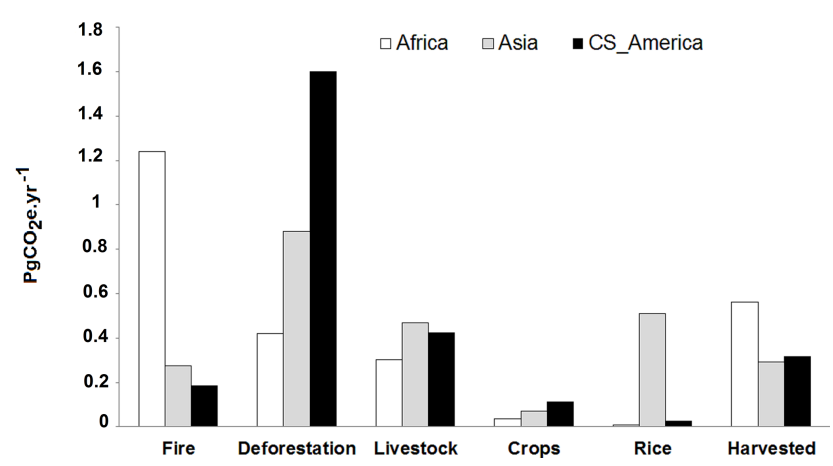

Figure 7. Continental contribution of the leading emission sources in our hotspot dataset, in the tropics, for the period 2000-2005.

of whether we are working with gross or net emissions, the timescale under analysis (e.g. 5 years in our study) and the selected methodological assumptions will strongly influence the final AFOLU estimates (e.g. exclusion of indirect emissions, exclusion of non-managed land, exclusion of legacy emissions, consideration of instantaneous emissions, exclusion of transboundary effects) and mitigation options (e.g. exclusion of substitution effects).

Assessments of net AFOLU emissions would be closer to what countries are requested to report under the United Nations Framework Climate Change Convention, but how different would they be from our gross hotspots results? We argue that, under our short-term temporal analysis (5 years), the spatial location of our gross AFOLU hotspots would not differ much, although the absolute emission estimates could be lower. Thus, for agriculturally driven hotspots (crops, livestock, rice), assessments of gross and net emissions would result in the same hotspots of AFOLU emissions because only soil organic storage acts as a sink to compensate against agricultural non- $\mathrm{CO}_{2}$ emissions, and soil carbon storage rates are small and short-lived (Smith et al., 2008). For areas with extended forests, gross and net AFOLU hotspots can differ. This would not be the case for areas affected by large-scale deforestation and/or intense degradation because the 5-year time frame of our study would not allow for significant carbon recovery after disturbance. Most of the differences between gross and net emissions would then concentrate in two forested areas: (i) those undergoing large-scale, high-density removals (e.g. afforestation/reforestation processes) such as in China - not included in this research - Vietnam, and India and (ii) forested areas affected by smaller-scale disturbances and less intense carbon processes that do not lead to deforestation, where forest emissions could be compensated by removals from the standing forests. Main differences between gross and net land use hotspot assessments in the tropics would then concentrate on areas with extended forests undergoing small-scale mid-level disturbances: Amazonian areas out of the arch of deforestation, wood harvesting in the 
Congo Basin, and lower impact disturbances in Mesoamerica, including Mexico.

This study also contributes to the debate on tropical mitigation potentials of agriculture and forestry. Thus, even if global estimates of agriculture and forestry emissions have roughly similar mitigation potentials (Smith et al., 2014; Tubiello et al., 2015), economic feasibilities differ. Forests have 2- to 3-fold greater economic mitigation potentials than agriculture (e.g. $0.2-13$ vs. $0.3-4.6 \mathrm{Pg} \mathrm{CO}_{2} \mathrm{e} \mathrm{yr}^{-1}$ respectively) at prices up to $100 \mathrm{USD} / \mathrm{Mg} \mathrm{CO}_{2}$ e (Bajzelj et al., 2014; Havlik et al., 2014; Smith et al., 2014). This means that for the same price, more emission reductions can be achieved in the forest sector. These unequal results relate to the forests sector being much more carbon dense, and they also relate to lower costs per area unit to monitor and implement actions against deforestation and degradation as well as to concerns about food security and adaptation needs (Smith et al., 2013; Havlik et al., 2014; Wollenberg et al., 2016). Thus, notwithstanding the importance of agricultural mitigation, forests are more cost-effective alternatives, and although uncertain, their multiple ecosystem services will keep them high as desirable mitigation targets on the political agenda.

\section{Data availability}

Country statistics are available in the Supplement. GIS data are freely available and can be downloaded from https://www.wageningenur.nl/en/project/Agriculture _ Forestry_and_Other_Land_Use.htm.

\section{The Supplement related to this article is available online at doi:10.5194/bg-13-4253-2016-supplement.}

\begin{abstract}
Author contributions. Rosa Maria Roman-Cuesta, Mariana C. Rufino, Martin Herold, Klaus Butterbach-Bahl, Todd S. Rosenstock, John Stuiver, and Louis Verchot designed the study. Rosa Maria Roman-Cuesta, Martin Herold, Christopher Martius, Changsheng Li, Stephen Ogle, and Benjamin Poulter provided data and ran quality control, quality assessments, and expert uncertainty judgements on the data sets. Sytze de Bruin guided us on statistics and developed all the scripts for the Monte Carlo aggregation of the data. John Stuiver assisted with GIS analyses and scripts. Rosa Maria Roman-Cuesta, Mariana C. Rufino, Martin Herold, Klaus Butterbach-Bahl, Todd S. Rosenstock, Sytze de Bruin, Louis Verchot, Christopher Martius, John Stuiver, Martin Herold, Changsheng Li, Stephen Ogle, and Benjamin Poulter discussed the results and contributed to writing.
\end{abstract}

Acknowledgements. This research was generously funded by the Standard Assessment of Mitigation Potential and Livelihoods in Smallholder Systems (SAMPLES) Project as part of the CGIAR
Research Program Climate Change, Agriculture, and Food Security (CCAFS). Funding also came from two European Union FP7 projects: GEOCarbon (283080) and Independent Monitoring of GHG Emissions no. CLIMA.A.2/ETU/2014/0008. Partial funds came through CIFOR from the governments of Australia (Grant Agreement no. 46167) and Norway (Grant Agreement no. QZA-10/0468). In memoriam Changsheng Li. The authors of this manuscript would like to honour Changsheng Li for his lifelong dedication to science.

Edited by: F. Joos

Reviewed by: B. Stocker, R. A. Houghton, and one anonymous referee

\section{References}

Alencar, A., Asner, G., Knapp, D., and Zarin, D.: Temporal variability of forest fires in eastern Amazonia, Ecol. Appl., 21, 23972412, 2011.

Alencar, A., Brando, P., Asner, G., and Putz, F.: Landscape fragmentation, severe drought, and the new Amazon forest fire regime, Ecol Appl., 25, 1493-1505, 2015.

Anderson, K.: The inconvenient truth of carbon offsets, Nature, 484, 7, doi:10.1038/484007a, 2012.

Anderson, K.: Duality in climate science, Nat. Geosci., 8, 898-900, 2015.

Asner, G., Powel, G., Mascaro, J., Knapp, D.,Clark, J., Jacobson J., Kennedy-Bowdoin T., Balaji A., Paez-Acosta, G., Victoria, E., Secada, L., Valqui, Mi., and Flint Hughes, R.: High resolution forest carbon stocks and emissions in the Amazon, P. Natl. Acad. Sci. USA, 107, 16738-16742, 2010.

Baccini, A., Goetz, S., Walker, W., Laporte, N., Sun, M., SullaMensashe, D., Hackler, J., Beck, P., Dubayah, R., Friedl, M., Samanta, S., and Houghton, R.: Estimated carbon dioxide emissions from tropical deforestation improved by carbon-density maps, Nature Climate Change, 2, 182-185, 2012.

Bajzelj, B., Richards, K., Allwood, J., Smith, P., Dennis, J., Curmi, E., and Gilligan, C.: Importance of food-demand management for climate mitigation, Nature Climate Change, 4, 924-929, 2014.

Balch, J., Andrade, R., Parsons, A., Armenteras, D., Roman-Cuesta, R. M., and Bulkan, J.: A synthesis of tropical forest degradation scenarios and carbon stock trajectories for REDD+, Conserv. Biol., under review, 2016.

Berenguer, E., Ferreira, J., Gardner, T., Aragao, L., BarbosaDeCarmargo, P., Cerri, C., Durigan, M., Cosme de Olivera, R., Vieira, C., and Barlow, J.: A large-scale field assessment of carbon stocks in human-modified tropical forests, Glob. Change Biol., 20, 3713-3726, 2014.

Bodle, R., Donat, L., and Duwe, M.: The Paris Agreement: Analysis, Assessment and Outlook, German Federal Environment Agency (UBA) Research Paper, Dessau-Roßlau: Umweltbundesamt, available at: http://ecologic.eu/13321, last access: 27 July 2016.

Brando, P., Balch, J., Nepstad, D., Morton, D., Putz, F., Coe, M., Silverio, D., Macedo, M., Davidson, E., Nobrega, C., Alencar, A., and Soares-Filhio, B: Abrupt increases in Amazonian tree mor- 
tality due to drought-fire interactions, P. Natl. Acad. Sci. USA, 11, 6347-6352, 2014.

Brienen, R., Phillips, O., Feldspausch, T., Gloor, E., Lloyd, J., Lopez-Gonzalez, G., Morteagudo-Mendoza, A., Malhi, Y., Lewis, S., Vasquez Martinez, R., Alexiades, M., Alvarez, E., Alvarez-Loayzada, P., and Zagt, R.: Long term decline of the Amazon carbon sink, Nature, 519, 344-361, 2015.

Canadell, J. and Schulze, D.: Global potential of biospheric carbon management for climate mitigation, Nat. Commun., 5, 52825293, 2014.

Carter, S., Herold, M., Rufino, M. C., Neumann, K., Kooistra, L., and Verchot, L.: Mitigation of agricultural emissions in the tropics: comparing forest land-sparing options at the national level, Biogeosciences, 12, 4809-4825, doi:10.5194/bg-12-4809-2015, 2015

Climate Focus: Forest and land use in the Paris Agreement, Climate Focus Brief on the Paris Agreement, available at: http://www.climatefocus.com/sites/default/files/ 20151223LandUseandtheParisAgreementFIN.pdf (last access: 27 July 2016), 2015

Cochrane, M., Alencar, A., Schulze, M., Souza, C., Nepstad, D., Lefebvre, P., and Davidson, E.: Positive feedbacks in the fire dynamics of closed canopy tropical forests, Science, 284, 18321835, 1999.

EDGAR: The Emissions Database for Global Atmospheric Research, Part III: Greenhouse gas emissions, available at: http: //edgar.jrc.ec.europa.eu/docs/IEA_PARTIII.pdf (last access: 27 July 2016), 2012.

FRA: Forest Resources Assessment, available at: http://www.fao. org/forestry/fra/fra2010/en/ (last access: 27 July 2016), 2010.

Federici, S., Tubiello, F., Salvatore, M., Jacobs, H., and Schmidhuber, J.: New estimates of $\mathrm{CO}_{2}$ forest emissions and removals: 1990-2015, Forest Ecol. Manag., 3, 89-98, 2015.

Federici, S., Grassi, G., Harris, N., Lee, D., Neeff, T., Penman, J., Sanz-Sanchez, M., and Wolosin M.: GHG fluxes from forests: an assessment of national reporting and independent science in the context of the Paris Agreement, Working Paper, UCLA, San Francisco, available at: http://www.climateandlandusealliance.org/wp-content/uploads/ 2016/06/GHG_Fluxes_From_Forests_Working_Paper.pdf, last access: 27 July 2016.

Gaveau, D., Salim, M., Hergoualc'h, K., Locatelli, B., Sloan, S., Wooster, M., Marlier, M., Molidena, E., Yoen, H., DeFries, R., Verchot, L., Murdisarso, D., Nasi, R., Holgrem, P., and Sheil, D.: Major atmospheric emissions from peat fires in Southeast Asia during non-drought years: evidence from the 2013 fires, Sci. Rep., 4, 6112-6119, 2014.

Gibbs, H., Ruesch, A., Achard, F., Clayton, M., Holmgren, P., Ramankutty, N., and Foley, A.: Tropical forests were the primary sources of new agricultural land in the 1980s and 1990s, P. Natl. Acad. Sci. USA, 107, 16732-16737, 2010.

Grace, J., Mitchard, E., and Gloor, E.: Perturbations in the carbon budget of the tropics, Glob. Change Biol., 20, 3238-3255, 2014.

Grassi, G., Monni, S., Federici, S., Achard, F., and Mollicone, D.: Applying the conservativeness principle to REDD to deal with uncertainties of the estimates, Environ. Res. Lett., 3, 035005035017, 2008.

Grassi, G. and Dentener, F.: Quantifying the contribution of the Land Use Sector to the Paris Climate Agreement, The LULUCF sector within the Intended Nationally Determined Contributions, EUR 27561, JRC Science for Policy Report, Ispra, Italy, available at: http://publications.jrc.ec.europa.eu/repository/bitstream/ JRC98451/jrclulucf-indcreport.pdf (last access: 27 July 2016), 2015.

Hansen, M., Potapov, P., Moore, R., Hancher, M., Turubanova, S., Tuykavina, A., Thau, D., Stehman, S., Goetz, S., Loveland, T., Kommareddy, A., Egorov, A., Chini, L., Justice, C., and Townshend, J.: High-resolution global maps of 21st-century forest cover change, Science, 342, 850-853, 2013.

Harris, N., Brown, S., Hagen, S., Saatchi, S., Petrova, S., Salas, W., Hansen, M., Potapov, P., and Lotsch, A.: Baseline Map of Carbon Emissions from Deforestation in Tropical Regions, Science, 336, 1576-1578, 2012.

Havlik, P., Valin, H., Herrero, M., Obersteiner, M., Schmid, E., Rufino, M., Mosnier, A., Thornton, P., Böttcher, H., Conant, R., Frank, S., Fritz, S., Fuss, S., Kraxner, F., and Notenbaert, A.: Climate change mitigation through livestock system transitions, P. Natl. Acad. Sci. USA, 111, 3709-3714, 2014.

Herrero, M., Havlik, P., Valin, H., Notenbaert, A., Rufino, M., Thornton, P., Blümmel, M., Weiss, F., Grace, D., and Obesteiner, M.: Biomass use, production, feed efficiencies, and greenhouse gas emissions from global livestock systems, P. Natl. Acad. Sci. USA, 110, 20888-20893, 2013.

Houghton, R.: Aboveground forest biomass and the global carbon balance, Glob. Change Biol., 11, 945-958, 2005.

Houghton, R.: How well do we know the flux of $\mathrm{CO}_{2}$ from land-use change?, Tellus B, 62, 337-351, 2010.

Houghton, R.: Carbon emissions and the drivers of deforestation and forest degradation in the tropics, Curr. Opin. Environ. Sustain., 4, 597-603, 2012.

Houghton, R. A., House, J. I., Pongratz, J., van der Werf, G. R., DeFries, R. S., Hansen, M. C., Le Quéré, C., and Ramankutty, N.: Carbon emissions from land use and land-cover change, Biogeosciences, 9, 5125-5142, doi:10.5194/bg-9-5125-2012, 2012.

IPCC: Intergovernmental Panel on Climate Change, Guidelines for National Greenhouse gas Inventories, Vol. 4: Agriculture, Forestry and Other Land Use, edited by: Eggleston, S., Buendia, L., Miwa, K., Ngara, T., and Tanabe, K., IGES, Kanagawa, Japan, 2006.

IPCC: Changes in Atmospheric Constituents and in Radiative Forcing, in: Contribution of Working Group I to the Fourth Assessment Report of the Intergovernmental Panel on Climate Change: The Physical Science Basis, edited by: Solomon, S., Qin, D., Manning, M., Chen, Z., Marquis, M., Averyt, K. B., Tignor, M., and Miller, H. L., Cambridge University Press, Cambridge, United Kingdom and New York, NY, USA, 2007.

IPCC: Intergovernmental Panel on Climate Change, Summary for Policymakers, in: Climate Change 2014: Mitigation of Climate Change, Contribution of Working Group III to the Fifth Assessment Report of the Intergovernmental Panel on Climate Change, edited by: Edenhofer, O., Pichs-Madruga, R., Sokona, Y., , Farahani, E., Kadner, S., Seyboth, K., Adler, A., Baum, I., Brunner, S., Eickemeier, P., Kriemann, B., Savolainen, J., Schlomer, S., von Stechow, C., Zwickel, T., and Minx, J. C., Cambridge University Press, Cambridge, United Kingdom and New York, NY, USA, 2014.

Iversen P., Lee D., and Rocha M.: Understanding Land Use in the UNFCCC, Summary for Policymakers, available at: http://www. 
fcmcglobal.org/documents/Land_Use_Guide_Summary.pdf (last access: 27 July 2016), 2014.

Le Quéré, C., Peters, G. P., Andres, R. J., Andrew, R. M., Boden, T. A., Ciais, P., Friedlingstein, P., Houghton, R. A., Marland, G., Moriarty, R., Sitch, S., Tans, P., Arneth, A., Arvanitis, A., Bakker, D. C. E., Bopp, L., Canadell, J. G., Chini, L. P., Doney, S. C., Harper, A., Harris, I., House, J. I., Jain, A. K., Jones, S. D., Kato, E., Keeling, R. F., Klein Goldewijk, K., Körtzinger, A., Koven, C., Lefèvre, N., Maignan, F., Omar, A., Ono, T., Park, G.-H., Pfeil, B., Poulter, B., Raupach, M. R., Regnier, P., Rödenbeck, C., Saito, S., Schwinger, J., Segschneider, J., Stocker, B. D., Takahashi, T., Tilbrook, B., van Heuven, S., Viovy, N., Wanninkhof, R., Wiltshire, A., and Zaehle, S.: Global carbon budget 2013, Earth Syst. Sci. Data, 6, 235-263, doi:10.5194/essd-6-2352014, 2014.

Lewis, S., Lopez-Gonzalez, G., Sonké, B., Affum-Baffoe, K., Baker, T., Ojo, L., Phillips, O., Reitsma, J., White, L., Comiskey, J., Djuikouo, M., Ewango, E., Feldspausch, T., Reitsma, J., and Wöll, H.: Increasing carbon storage in intact African tropical forests, Nature, 457, 1003-1007, 2009.

Li, C.: Biogeochemical concepts and methodologies: Development of the DNDC model, Quaternary Sci., 21, 89-99, 2001.

Li, C., Salas, W., DeAngelo, B., and Rose, S.: Assessing alternatives for mitigating net greenhouse gas emissions and increasing yields from rice production in China over the next 20 years, $\mathbf{J}$. Environ. Qual., 35, 1554-1565, 2006,

Mbow, C.: Biogeoscience: Africa's greenhouse gas budget is in the red, Nature, 508, 192-193, 2014.

Monfreda, C., Ramankutty, N., and Foley, A.: Farming the planet: Geographical distribution of crop areas, yields, physiological types, and net primary production in the year 2000, Global Biogeochem. Cy., 22, 1022-1041, 2008.

Morton, D., Sales, M., Souza, C., and Griscom, B.: Historic emissions from deforestation and forest degradation in Mato Grosso Brazil: 1) source data uncertainties, Carbon Balance Management, 6, 18-31, 2011.

Ogle, S.,Breidt, F., Easter, M., Williams, S., and Paustian, K.: An empirically based approach for estimating uncertainty associated with modelling carbon sequestration in soils. Ecol. Modell., 205, 453-463, 2007.

Oliveras, I., Anderson, D., and Malhi, Y.: Application of remote sensing to understanding fire regimes and biomass burning emissions of the tropical Andes, Global Biogeochem. Cy., 28, 480496, 2014

Peters, G. P., Davis, S. J., and Andrew, R.: A synthesis of carbon in international trade, Biogeosciences, 9, 3247-3276, doi:10.5194/bg-9-3247-2012, 2012.

Poorter, L., Bongers, F., Aide, M., Almeyda-Zambrano, A., Balvanera, P., Becknell, J., Boukili, V., Brancalion, P., Broadbent, E., Chazdon, R., Craven, D., de Almedida-Cortez, J., Cabral, G., deJong, B., and Rozendaal, D.: Biomass resilience of Neotropical secondary forests, Nature, 530, 211-214, 2016.

Poulter, B.: Global Wood Harvest, Operational Global Carbon Observing System - GEOCARBON Project Report, 2015 (data available upon request), 2010.

Pütz,S., Groeneveld, J., Henle, K., Knogge, C., Martensen, A., and Metz, M.: Long-term carbon loss in fragmented Neotropical forests, Nat. Commun., 5, 5037-5045, 2014.
Richards, M., Bruun, T., Campbell, B., Huyer, S., Kuntze, V., Gregersen, L., Madsen, S., Oldvig, M., and Vasileiou, I.: How countries plan to address agricultural adaptation and mitigation: An analysis of Intended Nationally Determined Contributions, CGIAR Research Program on Climate Change, Agriculture and Food Security (CCAFS), Copenhagen, available at: https://cgspace.cgiar.org/rest/bitstreams/63683/retrieve (last access: 27 July 2016), 2015.

Richter, D. and Houghton, R. A.: Gross $\mathrm{CO}_{2}$ fluxes from land-use change: implications for reducing global emissions and increasing sinks, Carbon Manag., 2, 41-47, 2011.

Román-Cuesta, R. M., Carmona-Moreno, C., Lizcano, G., New, M., Silman, S., Knoke, T., Malhi, Y., Oliveras, I., Asbjornsen, H., and Vuille, M.: Synchronous fire activity in the tropical high Andes: an indication of regional climate forcing, Glob. Change Biol., 20, 1929-1942, 2014.

Román-Cuesta, R. M., Gracia, M., and Retana, J.: Environmental and human factors influencing fire trends in Enso and non-Enso years in tropical Mexico, Ecol. Appl., 13, 1177-1192, 2013.

Schulze, E., Luyssaert, S., Ciais, P., Freibauer, A., Janssens, I., Soussana, J., Smith, P., Grace, J., Levin, I., Thiruchittampalam, B., Heimann, McDolman, A., Valentini, R., Bousquet, P., Peylin, P., Peters, W., and Gash, J.: Importance of methane and nitrous oxide for Europe's terrestrial greenhouse-gas balance, Nat. Geosci., 2, 842-850, 2009.

Smith, P., Martino, D., Cai, Z., Gwary, D., Janzen, H., Kumar, P., McCarl, B., Ogle, S., O’Mara, F., Rice, C., Scholes, B., Sirotenko, O., Howden, M., McAllister, T., Pan, G., Romanenkov, V., Schneider, U., Towprayoon, S., Wattenbach, M., and Smith, J.: Greenhouse gas mitigation in agriculture, Philos. T. R. Soc. B., 363, 789-813, 2008.

Smith, P., Haberl, H., Popp, A., Erb, K., Lauk, C., Harper, R., Tubiello, F., Siqueira Pinto, A., Jafari, M., Sohi, S., Masera, O., Bottcher, H., Berndes, G., Bustamante, M., Al Ahammad, H., Clark, H., and Rose, S.: How much land-base greenhouse gas mitigation can be achieved without compromising food security and environmental goals?, Glob. Change Biol., 19, 2285-2302, 2013.

Smith, P., Bustamante, M., Ahammad, H., and Van Minnen, J.: Agriculture, Forestry and Other Land Use (AFOLU), in: Climate Change 2014: Mitigation of Climate Change, Contribution of Working Group III to the Fifth Assessment Report of the Intergovernmental Panel on Climate Change, edited by: Edenhofer, O., Pichs-Madruga, R., Sokona, Y. E., Farahani, E., Kadner, S., Seyboth, K., Adler, A., Baum, I., Brunner, S., Eickemeier, P., Kriemann, B., Savolainen, J., Schlomer, S., von Stechow, C., Zwickel, T., and Minx, J. C., Cambridge University Press, Cambridge, United Kingdom and New York, NY, USA, 2014.

Tian, H., Lu, C., Ciais, P., Michalak, A., Canadell, J., Saikawa, E., Huntzinger, D., Gurney, K., Sitch, S., Zhang, B., Yang, J., Bousquet, P., Bruhwiler, L., Chen, G., Dlugokencky, E., and Wofsy, S.: The terrestrial biosphere as a net source of greenhouse gases to the atmosphere, Nature, 531, 225-228, 2016.

Tubiello, F., Salvatore, M., Cóndor Golec, R., Ferrara, A., Rossi, S., Biancalani, R., Federici, S., Jacobs, H., and Flammini, A.: Agriculture, Forestry and Other Land Use Emissions by Sources and Removals by Sinks 1999-2011 Analysis, Working Paper Series ESS/14-02, FAO Statistical Division, Rome, Italy, avail- 
able at: http://www.fao.org/docrep/019/i3671e/i3671e.pdf (last access: 27 July 2016), 2014.

Tubiello, F., Salvatore, M., Ferrara, A., House, J., Federici, S., Rossi, S., Biancalani, R., Condor Golec, R., Jacobs, H., Flammini, A., Prosperi, P., Cardenas-Galindo, P., Schmidhuber, J., Sanz Sanchez, M. J., Srivastava, N., and Smith, P.: The contribution of Agriculture, Forestry and other Land Use Activities to Global Warming, 1990-2012, Glob. Change Biol., 21, 26552660, 2015.

UNEP: United Nations Environmental Programme, The Emissions Gap Report 2015, Nairobi, available at: http://uneplive.unep.org/ theme/index/13\#indcs, 2015.

USEPA: United States Environmental Protection Agency, Global Mitigation of non- $\mathrm{CO}_{2}$ Greenhouse Gases: 2010 2030, Technical Report-430-R-13-011, available at: http://www.epa.gov/climatechange/Downloads/EPAactivities/ MAC_Report_2013.pdf (last access: 27 July 2016), 2013.

Van der Werf, G., Randerson, J., Giglio, L., Collatz, G., Mu, M., Kasibhatla, P., Morton, D., DeFries, R., Jin, Y., and van Leeuwen, T.: Global fire emissions and the contribution of deforestation, savannah, forest, agricultural, and peat fires (1997-2009), Atmospheric Chemistry and Physics, 10, 11707-11735, available at: The Global Fire Emission Database (GFED): http://www. globalfiredata.org (last access: 27 July 2016), 2010.
Wollenberg, L., Richards, M., Smith, P., Havlik, P., Obersteiner, M., Tubiello, F., Herold, M., Gerber, P., Carter, S., Reisinger, A., van Vuuren, D., Dickie, A., Neufeldt, H., Sander, B., Wassman, R., Sommer, R., Amonette, J., Falcucci, A., Herrero, M., Opio, C., Roman-Cuesta, R. M., and Campbell, B.: Reducing emissions from agriculture to meet the $2{ }^{\circ} \mathrm{C}$ target, Glob. Change Biol., doi:10.1111/gcb.13340, 2016. 